\title{
The Variation Characteristics and Influencing Factors of Base Flow of the Hexi Inland Rivers
}

\author{
Yuxin Lei ${ }^{1,2}$, Xiaohui Jiang ${ }^{1,2, *}$, Wenjie Geng ${ }^{2}$, Jinyan Zhang ${ }^{2}$, Huan Zhao ${ }^{2}$ and Liqing Ren ${ }^{3, *}$ \\ 1 Shaanxi Key Laboratory of Earth Surface System and Environmental Carrying Capacity, College of Urban and \\ Environmental Sciences, Northwest University, Xi'an 710127, China; leiyuxin@stumail.nwu.edu.cn \\ 2 Department of Environmental Engineering, College of Urban and Environmental Science, \\ Northwest University, Xi'an 710127, China; gengwenjie@stumail.nwu.edu.cn (W.G.); \\ zhangjinyan@stumail.nwu.edu.cn (J.Z.); zhaohuan@stumail.nwu.edu.cn (H.Z.) \\ 3 Remote Sensing Center of Xinjiang Meteorological Bureau, Urumqi 830011, China \\ * Correspondence: xhjiang@nwu.edu.cn (X.J.); RenLiQingxj@163.com (L.R.); Tel.: +86-135-0382-1320 (X.J.)
}

check for updates

Citation: Lei, Y.; Jiang, X.; Geng, W.; Zhang, J.; Zhao, H.; Ren, L. The Variation Characteristics and Influencing Factors of Base Flow of the Hexi Inland Rivers. Atmosphere 2021, 12, 356. https://doi.org/ 10.3390 /atmos 12030356

Academic Editor: Sopan Patil

Received: 27 January 2021

Accepted: 5 March 2021

Published: 9 March 2021

Publisher's Note: MDPI stays neutral with regard to jurisdictional claims in published maps and institutional affiliations.

Copyright: (c) 2021 by the authors. Licensee MDPI, Basel, Switzerland. This article is an open access article distributed under the terms and conditions of the Creative Commons Attribution (CC BY) license (https:// creativecommons.org/licenses/by/ $4.0 /)$.
Abstract: The climate is becoming warmer and more humid in the inland area of northwestern China. In addition, human activities have changed the underlying surface of the river basin, and the instability of the runoff changes has intensified. As a component of river runoff, the base flow reflects the impacts of climate change and human activities. Therefore, it is necessary to carry out research on the change in the base flow and its influencing factors in the context of climate change and human activities. In this study, a base flow method suitable for the inland rivers in northwestern China was assessed, and the variation rules and influencing factors of the base flow were analyzed. The results reveal that since the 1980s, the base flow of the Hexi inland rivers has exhibited an increasing trend, and the growth rate has exhibited the following order: western > central > eastern. The Base Flow Index (the proportion of the base flow to the total runoff in a period) values are in the range of 0.45-0.65. Overall, the change in the base flow of the Hexi inland rivers is the result of the coupling of climate factors and land-use change. The influence of land-use change on the base flow of the Hexi inland rivers gradually weakens from east to west, except for the Xiying River, while the influence of climate change gradually increases. The contribution rates of land-use change to the base flow in the eastern, central, and western regions were $75 \%, 55 \%$, and $27 \%$. Temperature and precipitation are the main climate factors affecting the change in the base flow in the western and central regions, respectively.

Keywords: Hexi inland rivers; base flow; land-use change; climate change; principal component analysis; double-mass curve

\section{Introduction}

Base flow is a vital part of river runoff and is one of the most important hydrological characteristics in arid and semi-arid areas. It plays a significant role in many aspects, such as maintaining ecosystem health, water safety, industrial and agricultural water supply and constructing rainfall-runoff relationship models [1,2]. As a slow response to the precipitation in the dry river basin, the base flow often permeates and replenishes the river in the form of groundwater, which plays an important role in maintaining the continuous flow and the stability of the water source [3]. The base flow can participate in the water circulation and thus affect the water balance of the groundwater. Its variation characteristics are related to the climatic characteristics, hydrogeology, soil distribution, human activities, and other factors in the basin. Therefore, it is imperative that the base flow in arid and semi-arid areas be studied.

Hexi inland rivers are referring to rivers in the Hexi Corridor, which is a historical region in China. The Hexi inland river basin is located between the continuous mountains in the northwestern part of inland China. It is far away from the sea, its climate is dry, and 
the amount of potential evapotranspiration is much larger than the amount of precipitation. It is a typical resource-deficient area. Water is the most important factor restricting the social and economic development and ecological balance in this region [4-7]. The Hexi inland rivers are mainly sourced in the Qilian mountain area, which is a water resource formation area with glacial development $[8,9]$ and more precipitation. On the basis of climate warming, the increased infiltration rate caused by the thickening of the active layer of the frozen soil $[10,11]$ and the increase in the amount of ice and snow melt water have a positive effect on the supply of the base flow [12], which is beneficial to ensuring the stability of the runoff in the basin. Over the past half century, the Hexi inland river basin has experienced an increase in temperature at a rate (of $0.36 \pm 0.03^{\circ} \mathrm{C} / 10 \mathrm{yrs}$ ) [13], which is significantly higher than the average amount in China and globally, making this an area that is extremely sensitive to climate change. The increase in the annual average precipitation and evaporation is the inevitable result of climate change; i.e., the increase of temperature and the acceleration of the water cycle. The precipitation in northwestern China generally exhibits an obvious increasing trend, which is consistent with the transition from a warm and dry climate to a warm and wet climate proposed by Shi [14-17]. In addition, human activities have changed the underlying surface of the river basin [18], which is affected the flow cycle of the rivers in the Hexi inland river basin, and it intensified the instability of the runoff changes. As a component of river runoff, base flow not only reflects the impact of climate change and human activities, but it also plays an important role in maintaining river health and meeting economic and social water demands. Therefore, it is necessary to carry out research on the change in the base flow and its influencing factors in the context of climate change and human activities in the Hexi inland river basin.

In the past few decades, many scholars in China and abroad have conducted a great deal of research on the changes in the base flow and its influencing factors in arid and semi-arid areas. For instance, Mwakalil [19] used the statistical analyses to study the influence of the basin characteristics on the base flow in a semi-arid region in Tanzania. The results showed that the Base Flow Index (the proportion of the base flow to the total runoff in a period) was significantly correlated with the climate characteristics and the geological conditions; i.e., more precipitation and less evapotranspiration produced more base flow. Zhang [20] used the digital filter method to divide the base flow in the upper reaches of the Heihe River and pointed out that the change in the base flow was mainly affected by precipitation. In addition, the changes in the base flow were also affected by the recharge of ice and snow melt water, the special terrain of the mountainous area, and the decrease of forest area. Dong [21] found that on a long time scale, precipitation is the main factor influencing the change in the base flow of the Shule River. Moreover, the increase in the ice and snow melt water caused by the increase in temperature and the degradation of permafrost also indirectly affected the change in the base flow. Zhang [22] analyzed the trend of the base flow in the Loess Plateau in China using the double parameter filter method to separate the base flow, finding that the gradual increase in the base flow was mainly due to the implementation of soil and water conservation measures. Quan and Ma [23] used the digital filter method to divide and calculate the base flow of eight main rivers in the Shiyang River basin. Their results revealed that the base flow was closely related to precipitation, topography, and other factors. However, the previous base flow segmentation method for a certain basin is relatively simple, and the results obtained for the same basin using different segmentation methods are not identical, so the base flow cannot be accurately determined. Therefore, in order to develop a base flow segmentation method suitable for a specific area, it is necessary to compare the various methods to find the optimal method of calculating the base flow. In addition, the factors influencing the base flow are usually only qualitatively analyzed or the influence of human activities, which are dominated by land-use changes, are omitted, and no quantitative analysis of the factors influencing the base flow change of the Hexi inland rivers has been conducted.

The results obtained for the base flow and driving factors in the Hexi inland rivers through various methods differ, and there is a lack of quantitative calculations of the 
contribution rates of the influencing factors. Therefore, using five types of base flow segmentation methods and the principal component analysis method, this study aims to analyze the variation of the base flow in the Hexi inland river basin by comparing the various methods and quantitatively discuss the driving factors of the base flow change from the aspects of climate and human activities. The results of this study provide a basis for the sustainable development and utilization of the water resources in the study area.

\section{Study Area}

The Hexi inland river basin is located in the northwestern arid region and is an inland basin on the edge of the Qinghai-Tibetan Plateau $\left(37^{\circ} 17^{\prime}-42^{\circ} 48^{\prime} N, 93^{\circ} 23^{\prime}-104^{\circ} 12^{\prime}\right.$ E). From east to west, there are three major water systems: the Shiyang River, the Heihe River, and the Shule River, all of which originate on the northern slope of the Qilian Mountains (Figure 1). The annual average precipitation in the basin increases from 35 to $800 \mathrm{~mm}$ from northwest to southeast, and the potential evapotranspiration increases from 985 to $3500 \mathrm{~mm}$ from southeast to northwest [24-26]. The annual average temperature is $3.3^{\circ} \mathrm{C}$, which is a typical of an inland arid climate [27]. The glaciers and permafrost in the Hexi inland river basin are mostly distributed in the upper Qilian Mountains, and the recharge from glacial melt water in the basin accounts for about $13.8 \%$ of the runoff (the main stream of the Shule River accounts for 32.8\%) [28]. The Shiyang River basin has a typical continental temperate arid climate, with large temperature differences, large amounts of potential evapotranspiration, and less precipitation. Overall, the spatial distribution of potential evapotranspiration increased gradually from south to north [29]. The sources of river recharge are mountain precipitation and high mountain ice and snow melt water. The Heihe River basin, which is located in the middle of the Hexi inland river basin, is the second largest inland river in the arid area of northwestern China. The Heihe River basin is mainly affected by the westerly band circulations [30] and cold polar air masses, which produces a typical arid region climate. The runoff in the basin mainly comes from glacial snow melt water and mountain precipitation [31]. The forest vegetation in the upper Qilian Mountains is mostly dominated by Picea crassifolia Kom in Qinghai. The Shule River basin is located in the western part of the Hexi inland river basin in Gansu Province. The Shule River basin has a dry and cold, continental arid desert climate, with less rain and more wind. The precipitation is mainly affected by the Atlantic water vapor carried by the westerly circulation, exhibiting vertical and horizontal distribution characteristics [32]. The runoff of the upper reaches of the Shule River is mainly recharged by precipitation, but ice and snow melt water recharge also occur. 


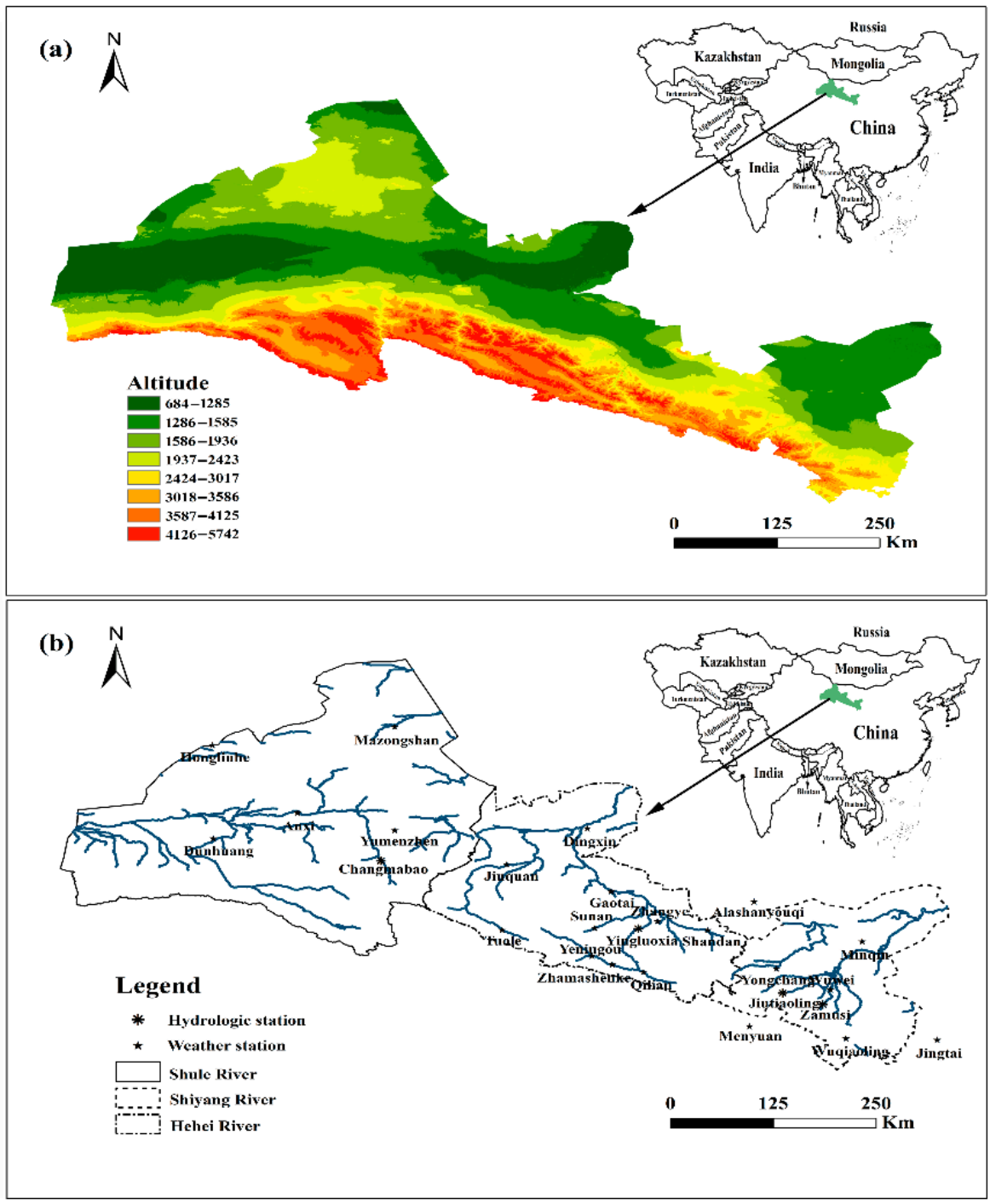

Figure 1. Overview of the Hexi inland rivers basin: (a) the elevation; (b) the river network, catchment area, and the observational stations.

\section{Data Sources and Research Methods}

\subsection{Data Sources}

The runoff data used in this study are the daily runoff sequences from the control stations (Figure 1) at the exits of the Shule River basin, the Heihe River basin, and the Shiyang River basin, which are Changmabao Station in the Shule River basin and Yingluoxia Station in the Heihe River basin. Since there are many main streams in the Shiyang River basin, one river with a large annual runoff was chosen on both the east and west sides to carry out the study. Zamusi Station is on the Zamu River and Jiutiaoling Station is on the Xiying River. All the original data used in this paper are complete. The daily runoff data were measured by the hydrological stations, and the data were downloaded from the Scientific Data Center of Dry Regions in Cold Regions (http:/ / westdc.westgis.ac.cn/, accessed on 8 July 2020). The daily base flow data were derived from the segmentation of the daily runoff data of the four rivers in the Hexi inland rivers basin using five base flow segmentation methods, and the base flow data series from 1980 to 2016 was intact.

The meteorological data used included precipitation and temperature data for the areas in and around the Shule River basin, the Heihe River basin, and the Shiyang River basin. The meteorological data were daily data downloaded from the National Meteorological Data Center of China (http:/ / data.cma.cn/, accessed on 8 July 2020). Based on the daily average temperature, maximum temperature, minimum temperature, average 
relative humidity, sunshine hours, and average wind speed, the potential evapotranspiration (PET) was calculated using the Penman-Monteith method [33,34]. Since the weather stations are scattered, if the data for the individual stations are used to analyze the climate of the entire basin, as has been done in previous studies, there will be a large error. In this study, the altitude data were taken as the covariant, and the average precipitation, temperature, and PET were obtained through the Anusplin interpolation method. The grid precision of the interpolation results is $30 \mathrm{~m} \times 30 \mathrm{~m}$. The details for the hydrological stations and weather stations are shown in Figure 1 and Table 1. Moreover, the land-use type map (Figure 2) was derived from the grid data for the Hexi inland rivers basin, which was divided by the land-use type in the three provinces in 1980, 1990, 1995, 2000, 2005, 2010, and 2015. These data were provided by the Resource and Environmental Science Data Center (http:/ / www.resdc.cn/, accessed on 8 July 2020) of the Chinese Academy of Sciences, with a resolution of $1 \mathrm{~km} \times 1 \mathrm{~km}$.

Table 1. Information on the hydrological and weather stations in the study area.

\begin{tabular}{|c|c|c|c|c|c|c|}
\hline Basin (Area) & $\begin{array}{c}\text { Stations } \\
\text { (Area) }\end{array}$ & Climate Parameter & Longitude/E & Latitude/N & Height $/ \mathrm{m}$ & Time Scale \\
\hline \multirow{9}{*}{$\begin{array}{l}\text { Shiyang River } \\
\text { basin } \\
\left(44,000 \mathrm{~km}^{2}\right)\end{array}$} & $\begin{array}{c}\text { Zamusi } \\
\left(660 \mathrm{~km}^{2}\right)\end{array}$ & $\mathrm{R}^{\mathrm{a}}$ & 102.57 & 38.70 & 2010.0 & 1980-2015 \\
\hline & $\begin{array}{l}\text { Jiutiaoling } \\
\left(1450 \mathrm{~km}^{2}\right)\end{array}$ & $\mathrm{R}$ & 102.05 & 37.87 & 2250.0 & 1980-2015 \\
\hline & Alashanyouqi & $\begin{array}{l}\mathrm{P}^{\mathrm{b}} \\
\mathrm{T}^{\mathrm{c}}\end{array}$ & 101.68 & 39.22 & 1510.1 & 1980-2015 \\
\hline & Yongchang & $\begin{array}{l}\mathrm{P} \\
\mathrm{T}\end{array}$ & 101.97 & 38.23 & 1976.9 & 1980-2015 \\
\hline & Wuwei & $\begin{array}{l}\mathrm{P} \\
\mathrm{T}\end{array}$ & 102.67 & 37.92 & 1531.5 & 1980-2015 \\
\hline & Minqin & $\begin{array}{l}\mathrm{P} \\
\mathrm{T}\end{array}$ & 103.08 & 38.63 & 1367.5 & 1980-2015 \\
\hline & Menyuan & $\begin{array}{l}\mathrm{P} \\
\mathrm{T}\end{array}$ & 101.62 & 37.38 & 7850.0 & 1980-2015 \\
\hline & Wuqiaoling & $\begin{array}{l}\mathrm{P} \\
\mathrm{T}\end{array}$ & 102.87 & 37.20 & 3045.1 & 1980-2015 \\
\hline & Jingtai & $\begin{array}{l}\mathrm{P} \\
\mathrm{T}\end{array}$ & 104.05 & 37.18 & 1630.9 & 1980-2015 \\
\hline \multirow{11}{*}{$\begin{array}{l}\text { Heihe River } \\
\text { basin } \\
\left(68,200 \mathrm{~km}^{2}\right)\end{array}$} & $\begin{array}{l}\text { Yingluoxia } \\
\left(10,400 \mathrm{~km}^{2}\right)\end{array}$ & $\begin{array}{l}R \\
P\end{array}$ & 100.18 & 38.82 & 3737.7 & 1980-2015 \\
\hline & Zhamashenke & $\mathrm{P}$ & 99.98 & 38.23 & 2820.0 & 1980-2015 \\
\hline & Dingxin & $\begin{array}{l}\mathrm{P} \\
\mathrm{T}\end{array}$ & 99.52 & 40.30 & 1177.4 & 1980-2015 \\
\hline & Jiuquan & $\begin{array}{l}\mathrm{P} \\
\mathrm{T}\end{array}$ & 98.48 & 39.77 & 1477.2 & 1980-2015 \\
\hline & Gaotai & $\begin{array}{l}\mathrm{P} \\
\mathrm{T}\end{array}$ & 99.83 & 39.37 & 1332.2 & 1980-2015 \\
\hline & Tuole & $\begin{array}{l}\mathrm{P} \\
\mathrm{T}\end{array}$ & 98.42 & 38.80 & 3367.0 & 1980-2015 \\
\hline & Sunan & $\begin{array}{l}\mathrm{P} \\
\mathrm{T}\end{array}$ & 99.62 & 38.83 & 2311.8 & 1980-2015 \\
\hline & Yeniugou & $\begin{array}{l}\mathrm{P} \\
\mathrm{T}\end{array}$ & 99.58 & 38.42 & 8320.0 & 1980-2015 \\
\hline & Zhangye & $\begin{array}{l}\mathrm{P} \\
\mathrm{T}\end{array}$ & 100.43 & 38.93 & 1482.7 & 1980-2015 \\
\hline & Qilian & $\begin{array}{l}\mathrm{P} \\
\mathrm{T}\end{array}$ & 100.25 & 38.18 & 2787.4 & 1980-2015 \\
\hline & Shandan & $\begin{array}{l}\mathrm{P} \\
\mathrm{T}\end{array}$ & 101.08 & 38.80 & 1764.6 & 1980-2015 \\
\hline
\end{tabular}


Table 1. Cont.

\begin{tabular}{|c|c|c|c|c|c|c|}
\hline Basin (Area) & $\begin{array}{l}\text { Stations } \\
\text { (Area) }\end{array}$ & Climate Parameter & Longitude/E & Latitude/N & Height $/ \mathrm{m}$ & Time Scale \\
\hline \multirow{6}{*}{$\begin{array}{l}\text { Shule River } \\
\text { basin } \\
\left(127,000 \mathrm{~km}^{2}\right)\end{array}$} & $\begin{array}{c}\text { Changmabao } \\
\left(11,400 \mathrm{~km}^{2}\right)\end{array}$ & $\mathrm{R}$ & 96.85 & 39.82 & 2080.0 & 1980-2015 \\
\hline & Hongliuhe & $\begin{array}{l}\mathrm{P} \\
\mathrm{T}\end{array}$ & 94.67 & 41.53 & 1573.8 & 1980-2015 \\
\hline & Mazongshan & $\begin{array}{l}\mathrm{P} \\
\mathrm{T}\end{array}$ & 97.03 & 41.80 & 1770.4 & 1980-2015 \\
\hline & Dunhuang & $\begin{array}{l}\mathrm{P} \\
\mathrm{T}\end{array}$ & 94.68 & 40.15 & 1139.0 & 1980-2015 \\
\hline & Anxi & $\begin{array}{l}\mathrm{P} \\
\mathrm{T}\end{array}$ & 95.77 & 40.53 & 1170.9 & 1980-2015 \\
\hline & Yumenzhen & $\begin{array}{l}\mathrm{P} \\
\mathrm{T}\end{array}$ & 97.03 & 40.27 & 1526.0 & 1980-2015 \\
\hline
\end{tabular}

${ }^{\mathrm{a}} \mathrm{R}$ stands for runoff. ${ }^{\mathrm{b}} \mathrm{P}$ stands for precipitation. ${ }^{\mathrm{c}} \mathrm{T}$ stands for temperature. The runoff in the table is calculated by the continuous measured discharge hydrograph method and temporary curve method, and the standard deviation of the main curve is $3.0 \%$.

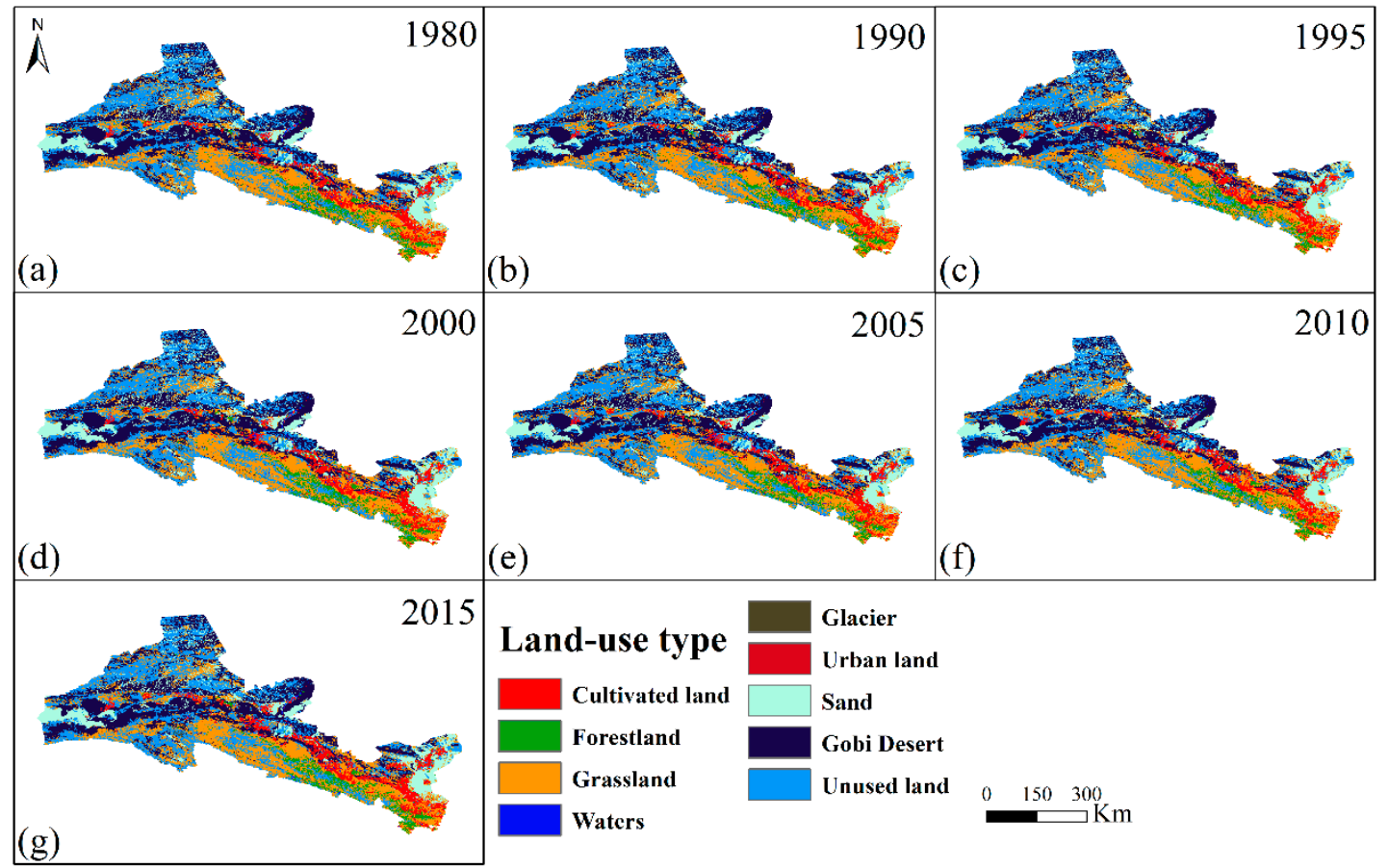

Figure 2. The land-use type map of the Hexi inland rivers basin: (a) 1980; (b) 1990; (c) 1995; (d) 2000; (e) 2005; (f) 2010; (g) 2015 .

\subsection{Research Methods}

\subsubsection{Base Flow Segmentation Method}

According to the principle of base flow segmentation, base flow segmentation methods can be divided into five general categories: graphic methods [35], digital analog methods [36,37], hydrological model methods [38], physical chemistry methods [39,40], and mathematical physics methods [41]. Referring to previous research results, in this study, the digital filter method and the minimum smoothed method were selected for the analysis.

The digital filter method is a fundamental flow segmentation method that has been widely studied in recent years. It is based on signal analysis and can decompose the signal into high frequency and low frequency signals using a digital filter [42]. This method was first proposed by Lyne and Hollick in 1979. In 1990, Nathan and McMahon [43] improved 
the algorithm. In this study, this modified algorithm is called the F1 method. The filtering equation is as follows:

$$
q_{t}=\beta q_{t-1}+[(1+\beta) / 2]\left(Q_{t}-Q_{t-1}\right)
$$

Base flow:

$$
b_{t}=Q_{t}-q_{t}
$$

$q_{t}$ is the fast response runoff (i.e., the direct runoff) at time $t\left(\mathrm{~m}^{3} / \mathrm{s}\right)$. $Q_{t}$ is the measured runoff $\left(\mathrm{m}^{3} / \mathrm{s}\right) . b_{t}$ is the base flow at time $\mathrm{t}\left(\mathrm{m}^{3} / \mathrm{s}\right) . \beta$ is the filter parameter, which adopts the value recommended by Nathan and McMahon (i.e., 0.925).

On this basis, Chapman and Maxwell [44] developed the F2 method in 1996, which introduced the recession coefficient. This filtering equation is as follows:

$$
q_{b(t)}=\frac{k}{2-k} q_{b(t-1)}+\frac{1-k}{2-k} Q_{t}
$$

In general, $k$ is the recession coefficient. In this study, $k$ was set as 0.95 .

The F3 method was proposed by Boughton [45] in 1993, and it was improved by Chapman and Maxwell in 1996. The filtering equation is as follows:

$$
q_{b(t)}=\frac{k}{1+C} q_{b(t-1)}+\frac{C}{1+C} Q_{t} .
$$

$C$ is a parameter, and in general, the value of $C$ is 0.15 .

Subsequently, Eckhardt improved the filter equation in 2005 and proposed the recursive digital filter method F4 [46], which includes two parameters: the water return constant $\alpha$ and $B F I_{\max }$. This filtering equation is as follows:

$$
b_{t}=\frac{\left(1-B F I_{\max }\right) \alpha b_{t-1}+(1-\alpha) B F I_{\max } Q_{t}}{1-\alpha B F I_{\max }} .
$$

The recession constant $\alpha$ was calculated using the Master Recession Curve method (MRC) [47] based on the daily runoff data for the Hexi inland rivers. According to the hydrological and geological conditions of the basin, the value of $B F I_{\max }$ recommended by Eckhardt [48] is 0.5 .

The minimum smoothed method (MSM) [49] attempts to divide the entire continuous flow sequence into non-nested blocks with $\mathrm{N}$ (the time step, day) as a unit, and then, it determines the minimum value in these blocks. These minimum values are combined according to certain rules to form inflection points, and each inflection point is connected to obtain the base flow sequence.

\subsubsection{Data Analysis Method}

The coefficient of variation (CV) [50] is a parameter used to measure the relative deviation degree of a series, which is the ratio of the standard deviation to the mean. CV is often used in mathematical statistics, which is also called deviation coefficient or the off-potential coefficient. CV is an index that reflects the change in the river runoff. If CV is larger, the sequence is more variable, and it is more discrete. If $\mathrm{CV}$ is smaller, the result is the opposite.

The dry water index [51] is an important index that reflects the runoff characteristics of groundwater recharge. $\mathrm{Q}_{\mathrm{a}}$ and $\mathrm{Q}_{\mathrm{b}}$ represent the runoff during the period when the frequency is greater than or equal to $90 \%$ and $50 \%$, respectively, which is determined using the diachronic curve of the daily flow. Base flow refers to the set of low flows that occurs during the dry season or between runoff events. Therefore, in this paragraph, the product of the dry water index $\left(Q_{a} / Q_{b}\right)$ and the total annual runoff was used as the actual observed value of the annual base flow. Base flow sequences obtained by the five segmentation methods are used as the estimated annual base flow. Then, in order to 
evaluate the applicability of these five base flow segmentation methods in each basin, the Nash-Sutcliffe efficiency coefficient [52] was used as the standard to evaluate the observed value and the estimated value. The formula is as follows:

$$
E=1-\frac{\sum_{i=1}^{n}\left(Q_{m(i)}-Q_{p(i)}\right)^{2}}{\sum_{i=1}^{n}\left(Q_{m(i)}-Q_{a m}\right)^{2}} .
$$

$E$ is the Nash-Sutcliffe efficiency factor. $Q_{m(i)}$ is the actual observed value of the annual base flow in the ith year $\left(10^{8} \mathrm{~m}^{3}\right) . Q_{p(i)}$ is the estimated annual base flow in the ith year $\left(10^{8} \mathrm{~m}^{3}\right) . Q_{a m}$ is the actual observed annual average base flow $\left(10^{8} \mathrm{~m}^{3}\right)$.

The value of $E$ is generally between $-\infty$ and 1 . The closer $E$ is to 1 , the better the estimation effect is. If $E$ is closer to $-\infty$, the effect is worse. The average relative error (R) was used to evaluate it:

$$
R=\frac{Q_{a s}-Q_{a m}}{Q_{a m}} .
$$

$Q_{a s}$ is the estimated annual average base flow $\left(10^{8} \mathrm{~m}^{3}\right)$. The closer $\mathrm{R}$ is to 0 , the better the simulation result. When $E$ is greater than 0.6 and $\mathrm{R}$ is less than $10 \%$, the results obtained from this base flow segmentation method have a good accuracy.

The Mann-Kendall test [53] method is often used in the analysis of rainfall and runoff to detect the long-term change trend and mutation of hydrological elements in a watershed. The Mann-Kendall test does not require samples to follow a certain distribution nor is it disturbed by a few outliers. It is suitable for hydrological, meteorological, and other data with non-normal distribution, and it is convenient to calculate.

In the Mann-Kendall test, the null hypothesis $H_{0}$ is the time series data $\left(X_{1}, \ldots, X_{n}\right)$, which is a sample of $n$ independent random variables identically distributed. The alternative hypothesis is that $\mathrm{H}_{1}$ is a bilateral test. For all $\mathrm{k}, \mathrm{j} \leq \mathrm{n}$, and $\mathrm{k} \neq \mathrm{j}$. The distribution of $X_{k}$ and $X_{j}$ is different. In the bilateral trend test, at a given confidence level of $\alpha$, the null hypothesis is not acceptable if the statistic shows $|Z|>Z_{1-\alpha / 2}$. In other words, at the confidence level of $\alpha$, the time-series data have an obvious upward or downward trend. For statistic $Z$, when it is greater than 0 , it is an upward trend. Less than 0 is a downward trend. When the absolute value of $Z$ is greater than or equal to $1.28,1.64$, and 2.32, it means that it has passed the significance test of $90 \%, 95 \%$, and $99 \%$ reliability, respectively [54].

\subsubsection{Principal Component Analysis}

Due to the many factors that affect the base flow, it is easy to produce data redundancy because of the driving force and self-correlation. Principal component analysis [55] is a multivariate statistical method. Principal component analysis after linear transformation uses fewer indicators to replace the original more numerous indicators. It can reflect the vast majority of the information of the original indicators, and there is no correlation between them.

In this study, the base flow was taken as the dependent variable $Y$, and the original land-use types were merged according to the actual composition of the land-use types in the Hexi inland rivers basin, which were divided into 9 land types for the statistical analysis. A total of 12 indicators were identified as independent variables (X1-X12) for the analysis, together with 3 selected climate factors. The variables are as follows: climate factor variables (Temperature X1, Precipitation X2, PET X3) and land-use type variables (Cultivated land X4, Forestland X5, Grassland X6, Waters X7, Glacier X8, Urban land X9, Sand X10, Gobi Desert X11, and Unused land X12).

Since land-use type maps were only available for 1980, 1990, 1995, 2000, 2005, 2010, and 2015, in order to maintain consistency in the lengths of the data series, the temperature, precipitation, and PET data were matched to the land-use type period using the average values of each set of five years. We assumed that land use was consistent between adjacent map dates (e.g., 1980 and 1990) and use a single land-use value for the period in between 
(i.e., 1980 land use for 1980-1989), but the annual values of the other variables. In addition, since the original data of each index have obvious differences in dimension and order of magnitude, the original data should be standardized before analysis in order to avoid errors caused by the influence of different dimensions in the calculation results. In this paper, the extreme method is used to standardize the original data.

\subsubsection{Double-Mass Curve Method}

The double-mass curve method can be used to establish the annual cumulative value regression relationship between precipitation and runoff. The change in the shape characteristics of the cumulative curve represents the change caused by the hydrological sequence under different influencing conditions. Once the cumulative runoff is calculated, the annual runoff can be reconstructed. Then, it can be used to calculate the contributions of climate change and human activities to the runoff change [56].

\section{Results}

\subsection{Base Flow Segmentation Results}

Since the characteristics of the Shule, Heihe, and Shiyang Rivers in Hexi inland rivers basin are different, this may increase the error based on lessons drawn directly from Chinese and foreign research results. Therefore, four types of digital filter methods (the Lyne-Hollick filtering method (F1), the Chapman-Maxwell filtering method (F2), the Boughton-Chapman filtering (F3), and the Eckhardt filtering (F4)) and the minimum smoothed method were used to obtain more realistic and effective base flow data, which conform comparatively well to the characteristics of the Hexi inland rivers basin. The five methods were compared and analyzed to improve the accuracy of the base flow estimation by selecting appropriate filter methods and parameters. For the purpose of determining which method was more suitable for this study area, the characteristics of the intra-annual and inter-annual base flow in the basin were analyzed. The results are shown in Tables 2 and 3.

Table 2. Statistical characteristics of the intra-annual base flow in the base flow separation methods applied to the Hexi inland rivers basin. ( $\mathrm{Kp}$, the extreme value ratio).

\begin{tabular}{|c|c|c|c|c|c|c|}
\hline \multirow{2}{*}{$\begin{array}{c}\text { Basin } \\
\text { (Hydrological Site) }\end{array}$} & \multirow{2}{*}{$\begin{array}{c}\text { Statistical } \\
\text { Characteristics }\end{array}$} & \multicolumn{4}{|c|}{ Digital Filter Method } & \multirow{2}{*}{ MSM } \\
\hline & & F1 & $\mathbf{F} 2$ & F3 & F4 & \\
\hline \multirow{5}{*}{$\begin{array}{l}\text { Shule River basin } \\
\text { (Changmabao) }\end{array}$} & $\operatorname{Max}\left(\mathrm{m}^{3} / \mathrm{s}\right)$ & 45.6 & 50.3 & 53.6 & 43.8 & 41.5 \\
\hline & $\operatorname{Min}\left(\mathrm{m}^{3} / \mathrm{s}\right)$ & 9.4 & 5.8 & 8.1 & 6.1 & 10.3 \\
\hline & Mean $\left(\mathrm{m}^{3} / \mathrm{s}\right)$ & 18.8 & 17.0 & 20.2 & 16.2 & 20.0 \\
\hline & $K p^{\mathrm{a}}$ & 4.84 & 8.70 & 6.59 & 7.25 & 4.03 \\
\hline & $\mathrm{CV}^{\mathrm{b}}$ & 0.62 & 0.88 & 0.77 & 0.76 & 0.56 \\
\hline \multirow{5}{*}{$\begin{array}{l}\text { Heihe River basin } \\
\text { (Yingluoxia) }\end{array}$} & $\operatorname{Max}\left(\mathrm{m}^{3} / \mathrm{s}\right)$ & 70.0 & 64.9 & 72.5 & 61.5 & 68.8 \\
\hline & $\operatorname{Min}\left(\mathrm{m}^{3} / \mathrm{s}\right)$ & 8.3 & 6.8 & 8.3 & 7.0 & 9.3 \\
\hline & Mean $\left(\mathrm{m}^{3} / \mathrm{s}\right)$ & 28.6 & 27.1 & 31.3 & 26.0 & 30.8 \\
\hline & $K p^{a}$ & 8.41 & 9.56 & 8.71 & 8.73 & 7.41 \\
\hline & $\mathrm{CV}$ & 0.77 & 0.82 & 0.78 & 0.79 & 0.72 \\
\hline \multirow{10}{*}{$\begin{array}{l}\text { Shiyang } \\
\text { River basin }\end{array}$} & $\operatorname{Max}\left(\mathrm{m}^{3} / \mathrm{s}\right)$ & 12.7 & 11.3 & 11.9 & 11.2 & 12.5 \\
\hline & $\operatorname{Min}\left(\mathrm{m}^{3} / \mathrm{s}\right)$ & 1.2 & 0.7 & 0.8 & 0.8 & 1.3 \\
\hline & Mean $\left(\mathrm{m}^{3} / \mathrm{s}\right)$ & 5.0 & 4.9 & 5.1 & 4.8 & 5.3 \\
\hline & $K p^{a}$ & 10.67 & 15.99 & 14.03 & 14.51 & 9.94 \\
\hline & $\mathrm{CV}$ & 0.86 & 0.86 & 0.86 & 0.83 & 0.82 \\
\hline & $\operatorname{Max}\left(\mathrm{m}^{3} / \mathrm{s}\right)$ & 8.5 & 7.9 & 8.3 & 7.7 & 8.6 \\
\hline & $\operatorname{Min}\left(\mathrm{m}^{3} / \mathrm{s}\right)$ & 0.8 & 0.5 & 0.6 & 0.5 & 0.8 \\
\hline & Mean $\left(\mathrm{m}^{3} / \mathrm{s}\right)$ & 3.6 & 3.6 & 3.8 & 3.6 & 3.8 \\
\hline & $K p^{a}$ & 11.25 & 16.89 & 14.52 & 14.62 & 10.91 \\
\hline & $\mathrm{CV}$ & 0.83 & 0.82 & 0.82 & 0.79 & 0.79 \\
\hline
\end{tabular}

${ }^{a}$ The extrema ratio. ${ }^{b}$ coefficient of variation. 
Table 3. Verification results of the inter-annual base flow separation methods applied to the Hexi inland rivers basin.

\begin{tabular}{ccccccccc}
\hline \multirow{2}{*}{$\begin{array}{c}\text { Separation } \\
\text { Methods }\end{array}$} & \multicolumn{2}{c}{ Shule River } & \multicolumn{2}{c}{ Heihe River } & \multicolumn{2}{c}{ Xiying River } & \multicolumn{2}{c}{ Zamu River } \\
\cline { 2 - 9 } & $\mathbf{E}^{\mathbf{a}}$ & $\mathbf{R}^{\mathbf{b}}$ & $\mathbf{E}$ & $\mathbf{R}$ & $\mathbf{E}$ & $\mathbf{R}$ & $\mathbf{E}$ & $\mathbf{R}$ \\
\hline F1 & 0.74 & $8.63 \%$ & 0.02 & $7.08 \%$ & 0.34 & $3.65 \%$ & 0.45 & $6.57 \%$ \\
F2 & 0.46 & $17.09 \%$ & -0.03 & $12.00 \%$ & 0.75 & $1.52 \%$ & 0.56 & $6.55 \%$ \\
F3 & 0.88 & $1.48 \%$ & 0.62 & $1.64 \%$ & 0.51 & $5.17 \%$ & 0.14 & $11.29 \%$ \\
F4 & 0.20 & $21.20 \%$ & -0.58 & $15.45 \%$ & 0.76 & $0.33 \%$ & 0.60 & $5.50 \%$ \\
MSM & 0.67 & $2.70 \%$ & -0.32 & $0.11 \%$ & -0.75 & $10.28 \%$ & -0.06 & $12.33 \%$ \\
\hline
\end{tabular}

a Nash-Sutcliffe efficiency coefficient. ${ }^{\mathrm{b}}$ Average relative error.

Since the base flow is the most important part to maintain a certain flow rate of a river, it has a relative stability and lag. Thus, the base flow sequence should be as gentle as possible, and the variation range should be small. As can be seen from Table 2, in the Shule River basin, the CV of the base flow sequence obtained using the F1 and the MSM are relatively small, with a minimum $\mathrm{CV}$ of 0.56 , followed by 0.62 . The $\mathrm{CV}$ of the base flow sequence for the Heihe River basin calculated using the five methods is similar, with a minimum CV of 0.72 , followed by F1 and F3. Similarly, the CV obtained using method F4 for the Xiying River and Zamu River was smaller than those for the other methods. The minimum CV of the MSM is 0.82 for the Xiying River, while the minimum CV for the Zamu River is 0.79 .

To further determine the optimal method of base flow segmentation, $E$ (the NashSutcliffe efficiency coefficient) was used to verify the accuracy of the inter-annual base flow segmentation method. Table 3 shows that the $E$ value of the base flow sequence of the Shule River obtained using F1 and MSM are all greater than 0.6, and the R (average relative error) values are less than $10 \%$, whereas the $E$ value of 0.74 is greater than that of the MSM (0.67). This indicates that both the F1 and MSM estimates have better accuracies, but F1 is more effective in comparison. The $E$ value of the F3 method for the Heihe River is 0.62 and the $\mathrm{R}$ value is $1.64 \%$, i.e., it is less than $10 \%$. Compared to the $\mathrm{F} 3$ method, the $E$ values of the other four methods are all less than 0.6 , and the estimations have poor performances. Similarly, the $E$ values of the base flow sequences obtained from the F2 and F4 methods for the Xiying River in the Shiyang River basin are greater than 0.6, with values of 0.75 and 0.76 , respectively. The $\mathrm{R}$ value of F4 is $0.33 \%$, which is less than that of $\mathrm{F} 2(1.52 \%)$, indicating that F4 is more suitable for the Xiying River. Only the $E$ value of the base flow sequence obtained using F4 for the Zamu River is equal to 0.60 and the $R$ value is less than $10 \%$ (i.e., $5.50 \%$ ). As a result, the applicability of the F4 method to these two rivers in the Shiyang River basin is higher.

In summary, combined with the verification results for the intra-annual and interannual base flow, the sequence for the Shule River basin was obtained selecting F1. F3 was chosen as the base flow segmentation method for the Heihe River basin, and the base flow data sequences for the Xiying River and Zamu River in the Shiyang River basin were calculated using the F4 method.

\subsection{Characteristics of Base Flow}

\subsubsection{Characteristics of the Intra-Annual Base Flow}

The base flow sequence obtained using the above determined base flow segmentation method was used to analyze the intra-annual variability of the base flow (Figure 3) of the four rivers in the Hexi inland rivers basin. The peak values of the runoff of the Shule, Heihe, Xiying, and Zamu Rivers all occurred in July, while the maximum value of the base flow lagged by one month. The variation range of the base flow was smaller than that of runoff, which has the characteristics of stability and lag. In addition, overall, the BFI (Base Flow Index) of the four rivers initially decreased and then increased. However, the variation range of BFI value in the Heihe River is relatively small, and the maximum BFI value in the other three rivers is about three times the minimum value. Furthermore, the 
maximum BFI value of the four rivers occurred in October, but the occurrence time of the minimum BFI value was different. The minimum BFI of the Shule River occurred in July, while for the remaining three rivers, it occurred in April.
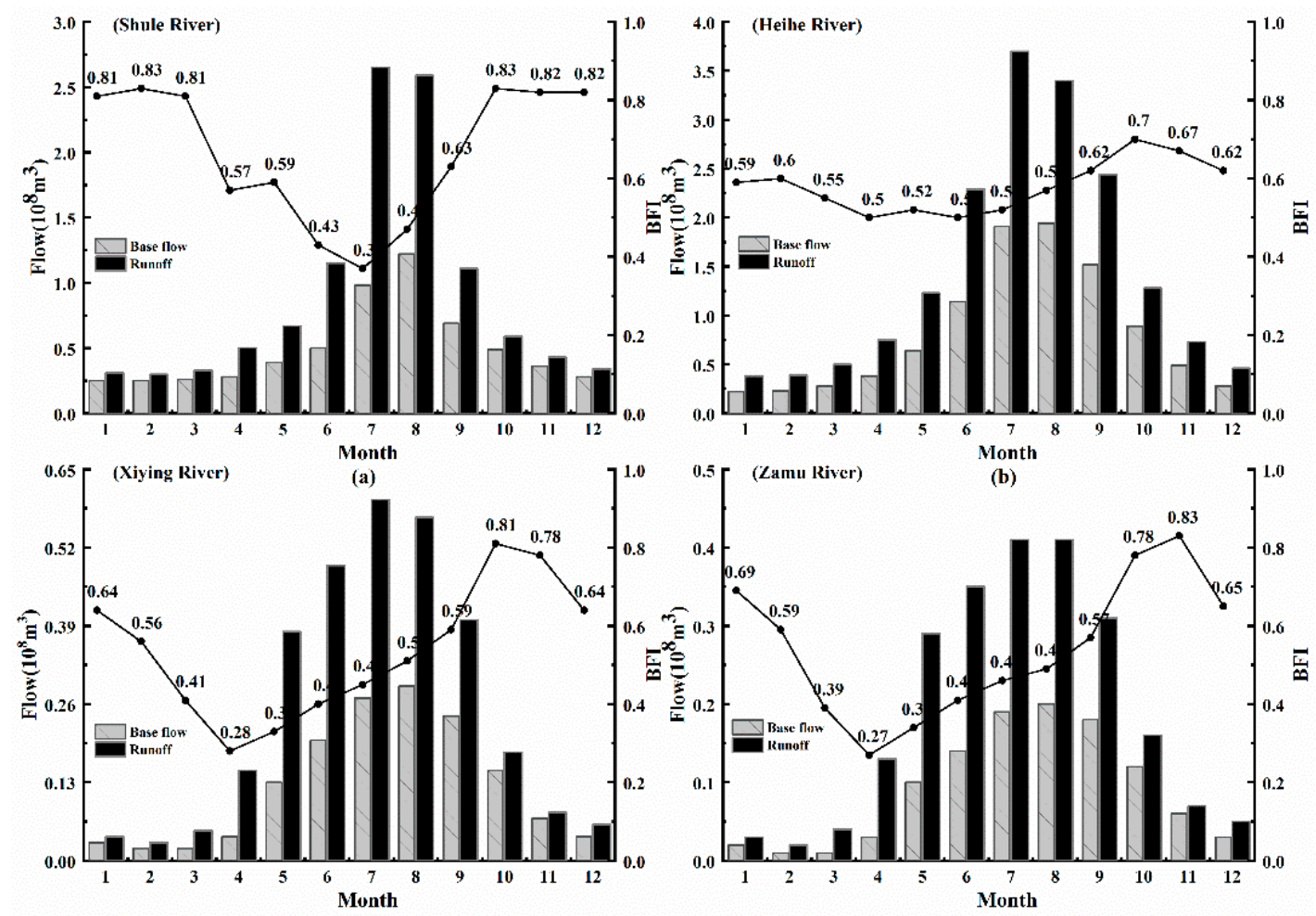

(c)

(d)

Figure 3. The trend of the intra-annual base flow, runoff, and BFI (Base Flow Index) values of the in Hexi inland rivers basin: (a) the Shule River; (b) the Heihe River; (c) the Xiying River; and (d) the Zamu River.

\subsubsection{Inter-Annual Distribution of the Base Flow and BFI}

In contrast to the initial increase and then decrease in the intra-annual base flow, the Shule River is the only one among the Hexi inland rivers where the inter-annual base flow shows a significant growth trend (Figure 4). Among the Hexi inland rivers, the average annual base flow of the Heihe River was the largest, followed by the Shule River. Those of the Xiying River and the Zamu River in the Shiyang River basin were only 10-20\% that of the Heihe River, and the base flow of the Xiying River was slightly larger than that of the Zamu River. The average annual base flow depth in the Heihe, Shule, Xiying, and Zamu Rivers were 95.38, 52.28, 105.52, and $171.21 \mathrm{~mm}$, respectively. In addition, from the perspective of the spatial distribution, the growth rate of the base flow in the Hexi inland river basin shows an obvious increasing trend from east to west. The increasing trend of the base flow in the Shule River was the most obvious (at a significant level of 0.01), which increased by $94 \%$ in the last 40 years at a rate of 103 million $\mathrm{m}^{3} / 10$ yrs (Table 4 ). However, through the M-K test of the trend, it was found that the growth trends of the other three inter-annual base flow were not obvious, and none of them passed the significance level test of 0.05 . Of these, the growth rate of the base flow in the Shule River was about three times faster than that of the Heihe River (33.1 million $\mathrm{m}^{3} / 10 \mathrm{yrs}$ ), 30 times that of the Xiying River ( 2.9 million $\mathrm{m}^{3} / 10 \mathrm{yrs}$ ), and 90 times that of the Zamu River (1.1 million $\left.\mathrm{m}^{3} / 10 \mathrm{yrs}\right)$. The general characteristics of the annual variations in the base flow are usually described by the coefficient of variation $(\mathrm{CV})$ and the annual extreme value ratio $\mathrm{Kp}$. The extremum ratio $\mathrm{Kp}$ is the ratio between the maximum annual base flow and the minimum annual base flow, and its size reflects the range of the inter-annual base flow [57]. Larger CV and Kp values indicate that the annual variation in the base flow is more intense, which is not conducive to the utilization of water resources. On the contrary, the variation in the annual abundance 
and dryness of the base flow is relatively stable, which is very beneficial to the utilization of water resources. The CV and $K p$ values of the four rivers (Heihe, Shule, Xiying, and Zamu) were calculated to be $0.14,0.26,0.19,0.19$ and $1.64,2.51,2.06,2.35$, respectively. Thus, the $\mathrm{CV}$ and $K p$ values of the rivers in the Hexi inland rivers basin are relatively small, which indicates that the annual variation in the base flow in the Hexi inland river basin is relatively stable. Among them, the CV and Kp values of the Heihe River are the smallest, while those of the Shule River are the largest.

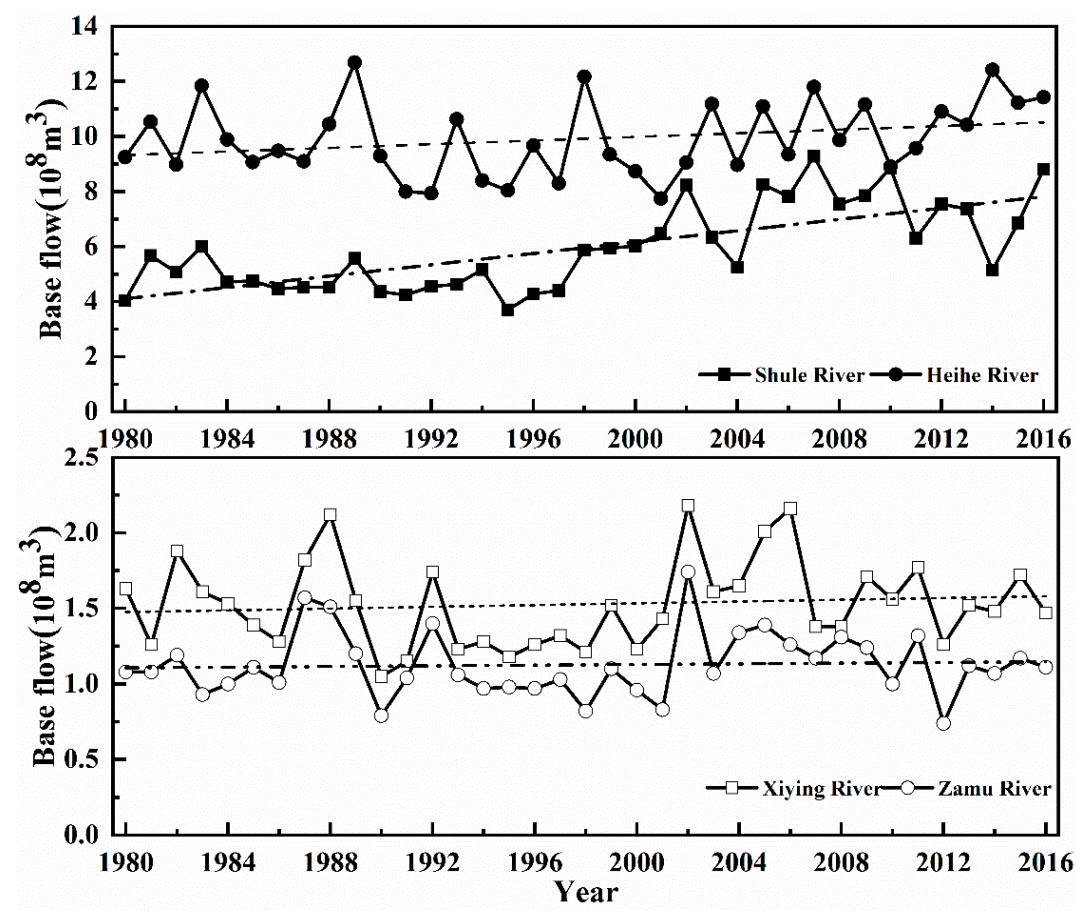

Figure 4. The trend of the inter-annual base flow in the Hexi inland rivers basin.

Table 4. The inter-annual variability of the base flow in the Hexi inland rivers basin.

\begin{tabular}{ccccccc}
\hline Basin & River & $\begin{array}{c}\text { Mean } \\
\left(\text { million } \mathbf{~ m}^{\mathbf{3}}\right)\end{array}$ & $\begin{array}{c}\text { Equation of Linear } \\
\text { Regression }\end{array}$ & $\begin{array}{c}\text { Coefficient of } \\
\text { Correlation }\left(\mathbf{R}^{\mathbf{2}}\right)\end{array}$ & $\begin{array}{c}|\mathbf{Z}| \\
\mathbf{P}\end{array}$ \\
\hline Heihe River basin & Heihe River & 992 & $\mathrm{y}=0.033 \mathrm{x}+9.29$ & 0.07 & 1.58 & 0.114 \\
Shule River basin & Shule River & 596 & $\mathrm{y}=0.103 \mathrm{x}+4.00$ & 0.50 & $4.07 *$ & $<0.01$ \\
Shiyang River basin & Xiying River & 153 & $\mathrm{y}=0.003 \mathrm{x}+1.47$ & 0.01 & 0.77 & 0.440 \\
& Zamu River & 113 & $\mathrm{y}=0.001 \mathrm{x}+1.11$ & 0.00 & 0.46 & 0.674 \\
\hline
\end{tabular}

${ }^{*}$ This means the change trend of inter-annual base flow is significant when $\alpha=0.01$.

Overall, the BFI values of the four rivers in the Hexi inland rivers basin fluctuate within the range of $0.45-0.65$. The annual average values of BFI in the Heihe, Shule, Xiying, and Zamu Rivers do not differ much: 0.569, 0.545, 0.486, and 0.487, respectively. (Figure 5) Compared with the change trend of the intra-annual BFI, the inter-annual fluctuation of the BFI is greater, but the range of the change is smaller. Except that the BFI values of the Heihe River exhibits a relatively obvious decreasing trend at a rate of $-0.017 / 10$ yrs, the growth trends of the other three rivers are not very significant, and they fluctuate near their multi-year mean. Among them, the maximum annual average BFI value of the Heihe River is 0.569 , which is followed by the Shule River (0.545). The Xiying River and Zamu River are both equal to about $85 \%$ that of the Heihe River. This shows that in recent years, under the combined action of climate factors and land-use changes, the growth rate of the runoff in the Heihe River has been much larger than that of the base flow, and the conversion rate of the surface runoff into base flow is decreasing. Moreover, as can be seen from Figure 5, the inter-annual variation in the BFI of the Shule River is relatively large, and its extreme value 
ratio is the largest in the Hexi inland rivers basin. This indicates that compared with the other basins, the fluctuation of the base flow of the Shule River is more obvious. In addition, the base flow variation trends of the Xiying River and Zamu river are similar, and the BFI values continue to increase to close to 0.5 , indicating that the base flow of the Shiyang River basin is an important part of the runoff, and its proportion gradually increases.
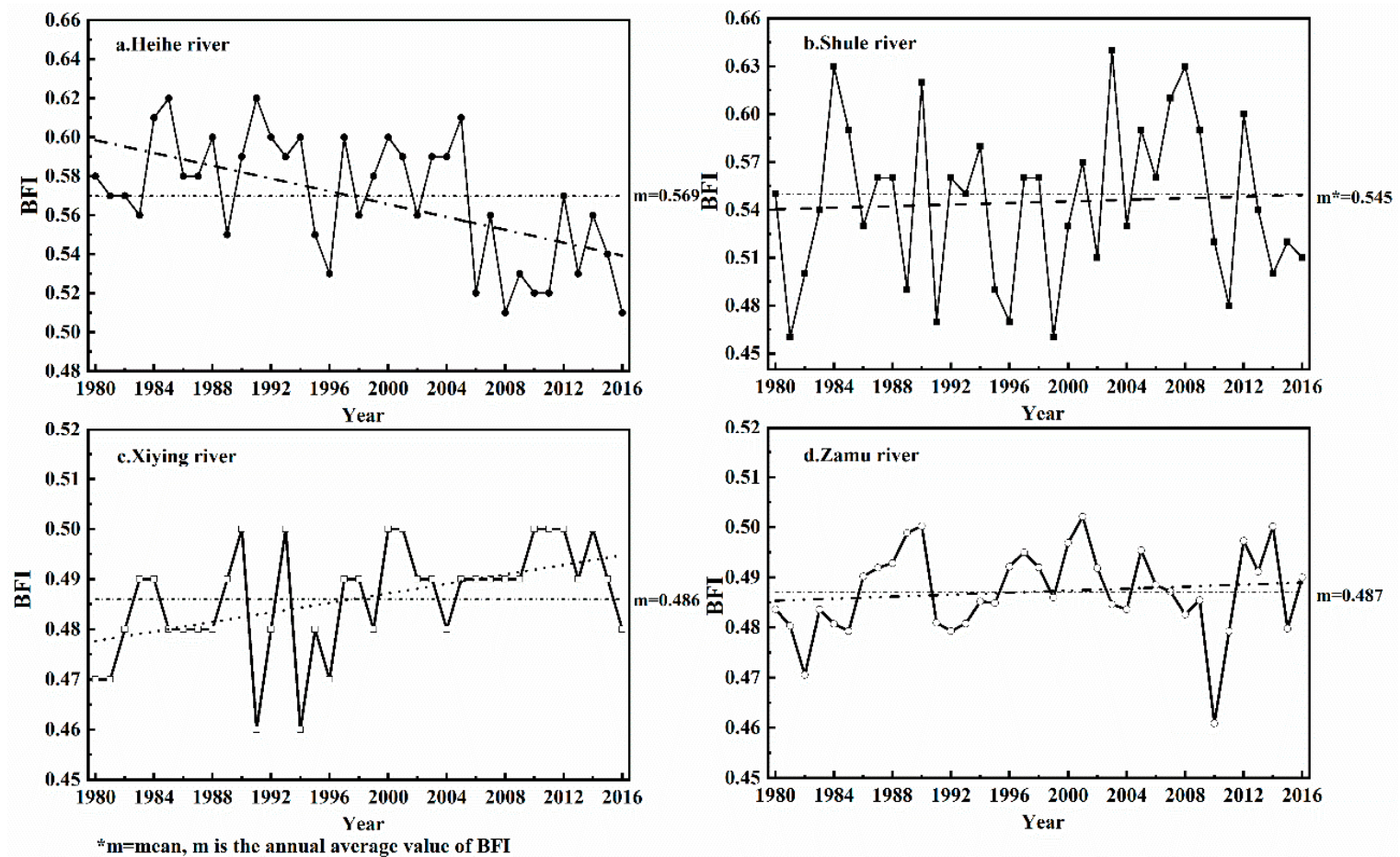

Figure 5. The trend of the inter-annual BFI in the Hexi inland rivers basin: (a) the Heihe River; (b) the Shule River; (c) the Xiying River; (d) the Zamu River.

\subsubsection{Characteristic Analysis of the Mutation of Base Flow}

For a clearer and more intuitive description of the inter-annual variation in the base flow in the Hexi inland rivers basin, the mutation points are identified using the cumulative anomaly curve of the Hexi inland rivers basin's base flow (Figure 6) and the Pettitt test [58] (at a significance level of 0.05). There is a discontinuity in the change in the weather processes. This discontinuity is called a mutation. If there is a sharp change from one statistical property to another before and after a reference point, then we consider that the system has a mutation at the reference point, and this reference point is called a mutation point [59]. It was found that the base flow of the Shule River mutated in 1997, that of the Heihe River mutated in 2002, and the base flow mutation points of the Xiying River and Zamu River occurred in 2001. Overall, the base flow of the Hexi inland rivers basin changed around 2000. During 1980-2000, the base flow continued to decrease, while it exhibited an increasing trend after 2000, among which the growth trend of the Shule River was the most obvious.

\subsection{Determination of the Factors Influencing the Base Flow}

A watershed's water cycle is a complex process, which is mainly affected by climate factors [60] (e.g., temperature, precipitation, PET, sunshine duration, and relative humidity), underlying surface factors [61] (e.g., topography, geomorphology, soil, and vegetation), and human activities (e.g., measures for building up water conservancy projects, land-use change, large-scale afforestation and other ecological restoration projects, and watershed water access). The evolution law of the base flow is the product of the interactions between climate change and the underlying surface changes in the watershed. Due to the number of factors affecting the base flow and the different climate and underlying surface conditions 
in each basin, in order to simplify the analysis process, principal component analysis (PCA) was used to represent and identify the driving factors of the base flow changes under different circumstances.

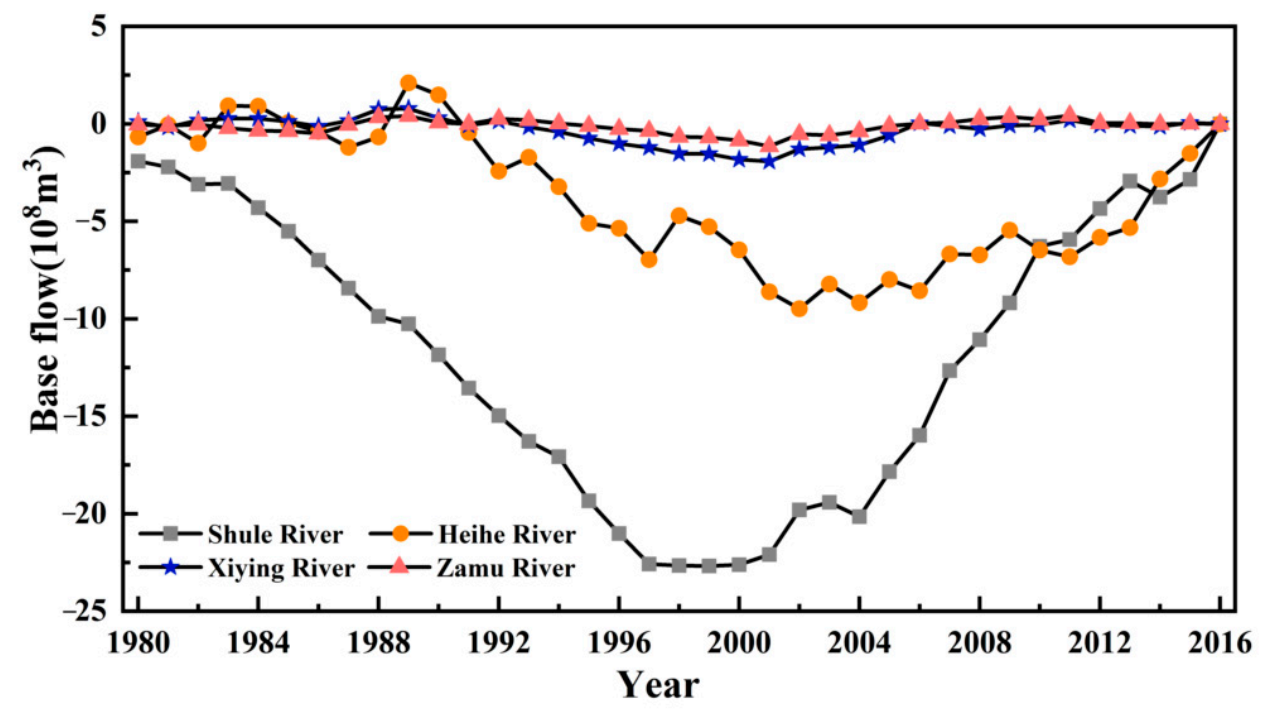

Figure 6. The cumulative anomaly curve of the base flow change in the Hexi inland rivers basin.

By selecting these 12 influencing factors (climate factor variables: Temperature $\mathrm{X} 1$, Precipitation X2, PET X3, and land-use type variables: Cultivated land X4, Forestland X5, Grassland X6, Waters X7, Glacier X8, Urban land X9, Sand X10, Gobi Desert X11, and Unused land $\mathrm{X} 12$ ) for the principal component analysis, the number of principal components in each basin was determined according to the size of the characteristic value and the contribution rate of the cumulative variance. The cumulative contribution rate of the first, second, and third principal components of the Shule River reached $95 \%$, which met the requirement that the cumulative contribution rate should be more than $85 \%$. This indicates that the three principal components can fully represent the original independent variable factors and can reflect the specific situation affecting the base flow in the Shule River Basin. In the same way, the cumulative contribution rate of the first, second, and third principal components of the Heihe River reached 93\%, and the cumulative contribution rate for the Shiyang River basin reached $92 \%$, so the number of principal components for the Hexi inland rivers basin was all three.

After the number of principal components was determined, the load of the initial factor on each principal component was calculated using the principal component load formula to form the initial load matrix. However, due to the non uniqueness of the initial load matrix, only part of the information for the variables could be represented. In order to express the variable information more clearly and comprehensively, the initial load matrix was rotated using Kaiser's Varimax rotation [62], which makes the matrix's structure relatively simple. It could be used to fully explain and analyze the principal components. The resulting postrotation composition matrix is shown in Table 5 . The absolute value of the load coefficient corresponding to each variable in the table reflects its importance in the corresponding principal component. As can be seen from Table 5, the load coefficient greater than 0.90 [63] in the first principal component of the Shule River is Temperature. In the second principal component, the driving factor load coefficient greater than 0.90 is Grassland and Urban land. The second principal component can be summarized as the impact of land-use change. For the correlation coefficient between the third principal component and PET, Forestland was the highest. The third principal component is summarized as the combined effect of climate change and land-use change. The load coefficient greater than 0.90 in the first principal component of the Heihe River includes PET, Sand, Gobi Desert, and Unused land. The first principal component is summarized as the combined effect of 
climate change and land-use change. In the second principal component, the driving factor load coefficient greater than 0.90 is Temperature. The overall load value of the third principal component is generally smaller than that of the first principal component. On the whole, only Precipitation has a load coefficient greater than 0.85 . In the same way, the load coefficient greater than 0.90 in the first principal component of the Shiyang River includes Precipitation, Urban land, and Sand. The first principal component is summarized as the combined effect of climate change and land-use change. In the second principal component, the driving factor with a load coefficient greater than 0.90 was PET. The coefficients of the third principal component load were all small, and the only driving factor greater than 0.90 was Forestland. Overall, there are climate factors and land-use change factors in the main influencing factors of each basin, which indicates that the change in the base flow in the Hexi inland rivers basin is the product of the joint action of climate factors and land-use factors. These two factors are inseparably interconnected. Therefore, the impact of land-use change cannot be ignored when analyzing the change in the base flow.

Table 5. Component matrix after rotation.

\begin{tabular}{cccccccccc}
\hline \multirow{2}{*}{ Factor } & \multicolumn{3}{c}{ Component of Shule River } & \multicolumn{2}{c}{ Component of Heihe River } & \multicolumn{3}{c}{ Component of Shiyang River } \\
\cline { 2 - 9 } & $\mathbf{1}$ & $\mathbf{2}$ & $\mathbf{3}$ & $\mathbf{1}$ & $\mathbf{2}$ & $\mathbf{3}$ & $\mathbf{1}$ & $\mathbf{2}$ & $\mathbf{3}$ \\
\hline Temperature & 0.94 & 0.13 & -0.09 & 0.35 & 0.92 & -0.04 & 0.84 & 0.06 & -0.42 \\
Precipitation & 0.36 & 0.65 & -0.65 & 0.42 & -0.01 & -0.86 & 0.94 & 0.29 & -0.13 \\
PET & -0.16 & -0.13 & -0.96 & -0.94 & -0.32 & 0.01 & -0.21 & 0.93 & 0.21 \\
Cultivated land & 0.86 & 0.49 & -0.01 & 0.78 & 0.58 & -0.20 & 0.87 & 0.15 & -0.39 \\
Forestland & -0.19 & -0.15 & 0.90 & 0.36 & 0.87 & -0.21 & -0.21 & -0.14 & 0.96 \\
Grassland & 0.21 & 0.94 & -0.02 & -0.42 & -0.88 & 0.13 & -0.72 & -0.53 & 0.19 \\
Waters & 0.45 & 0.27 & 0.81 & 0.24 & -0.18 & 0.84 & -0.16 & -0.89 & 0.35 \\
Glacier & -0.60 & -0.28 & 0.70 & -0.04 & -0.61 & 0.64 & -0.68 & 0.24 & 0.62 \\
Urban land & -0.29 & -0.94 & -0.02 & -0.88 & -0.45 & 0.14 & -0.94 & 0.24 & -0.14 \\
Sand & 0.80 & 0.58 & -0.03 & 0.96 & 0.24 & 0.01 & 0.90 & -0.06 & -0.38 \\
Gobi Desert & 0.47 & 0.87 & 0.02 & 0.93 & 0.31 & 0.08 & 0.86 & -0.34 & -0.24 \\
Unused land & 0.87 & 0.43 & 0.17 & 0.94 & 0.16 & -0.10 & 0.79 & 0.10 & -0.45 \\
\hline
\end{tabular}

After determining the principal component factors used in the analysis, it is necessary to calculate the specific values of the original indicators on the first, second, and third principal component factors-that is, to calculate the factor scores. Specific methods include the regression method, Bartlett method, etc. In this paper, the regression method is used to calculate the scores of each factor. In order to directly reflect the influence of the three principal component factors on the base flow, the score coefficient of each principal component in each period was calculated by using factor score (Table 6). The three principal component score coefficients were expressed as f1, f2, and f3, respectively. Equations (8) and (9) are used to calculate the score of comprehensive driving force $F$, and the points obtained are plotted in Figure 7. Wherein, $\mathrm{F}$ is the result of the weighted summary of score coefficients with the percentage of variance of each principal component in the total variance in the square sum of extraction load as the weight [63-65].

$$
\begin{aligned}
& \text { Shule River: } \mathrm{F}=\mathrm{f} 1 \times 0.6061+\mathrm{f} 2 \times 0.2899+\mathrm{f} 3 \times 0.1046 \text {. } \\
& \text { Heihe River: } \mathrm{F}=\mathrm{f} 1 \times 0.6943+\mathrm{f} 2 \times 0.1960+\mathrm{f} 3 \times 0.1097 \text {. } \\
& \text { Shiyang River: } \mathrm{F}=\mathrm{f} 1 \times 0.6868+\mathrm{f} 2 \times 0.2113+\mathrm{f} 3 \times 0.1018 \text {. }
\end{aligned}
$$


Table 6. Score coefficient of the principal component factors and the score of the comprehensive driving force in each period.

\begin{tabular}{|c|c|c|c|c|c|}
\hline Area & Period & F1 & F2 & F3 & $\mathbf{F}$ \\
\hline \multirow{7}{*}{ Shule River } & 1980 & -0.62 & -0.44 & 2.04 & -0.29 \\
\hline & 1990 & -1.14 & 0.07 & -0.18 & -0.69 \\
\hline & 1995 & -0.88 & -0.18 & -1.02 & -0.70 \\
\hline & 2000 & -0.27 & -0.48 & -0.76 & -0.38 \\
\hline & 2005 & 1.02 & -0.79 & -0.35 & 0.35 \\
\hline & 2010 & 1.50 & -0.37 & 0.19 & 0.82 \\
\hline & 2015 & 0.40 & 2.19 & 0.08 & 0.88 \\
\hline \multirow{7}{*}{ Heihe River } & 1980 & -0.12 & -1.45 & 1.28 & -0.23 \\
\hline & 1990 & -0.44 & -0.99 & -0.12 & -0.51 \\
\hline & 1995 & -0.87 & 0.13 & -0.54 & -0.64 \\
\hline & 2000 & -1.06 & 1.24 & 0.55 & -0.43 \\
\hline & 2005 & 0.01 & 0.93 & -0.02 & 0.19 \\
\hline & 2010 & 0.59 & -0.43 & -1.82 & 0.13 \\
\hline & 2015 & 1.89 & 0.56 & 0.68 & 1.50 \\
\hline \multirow{7}{*}{$\begin{array}{c}\text { Shiyang } \\
\text { River }\end{array}$} & 1980 & -1.24 & -1.71 & 0.20 & -1.20 \\
\hline & 1990 & -0.61 & 1.13 & 0.58 & -0.12 \\
\hline & 1995 & -0.39 & 0.25 & 0.57 & -0.16 \\
\hline & 2000 & -0.35 & 0.18 & -0.22 & -0.22 \\
\hline & 2005 & 0.47 & 0.91 & 0.49 & 0.57 \\
\hline & 2010 & 0.24 & 0.16 & -2.17 & -0.02 \\
\hline & 2015 & 1.88 & -0.93 & 0.56 & 1.15 \\
\hline
\end{tabular}

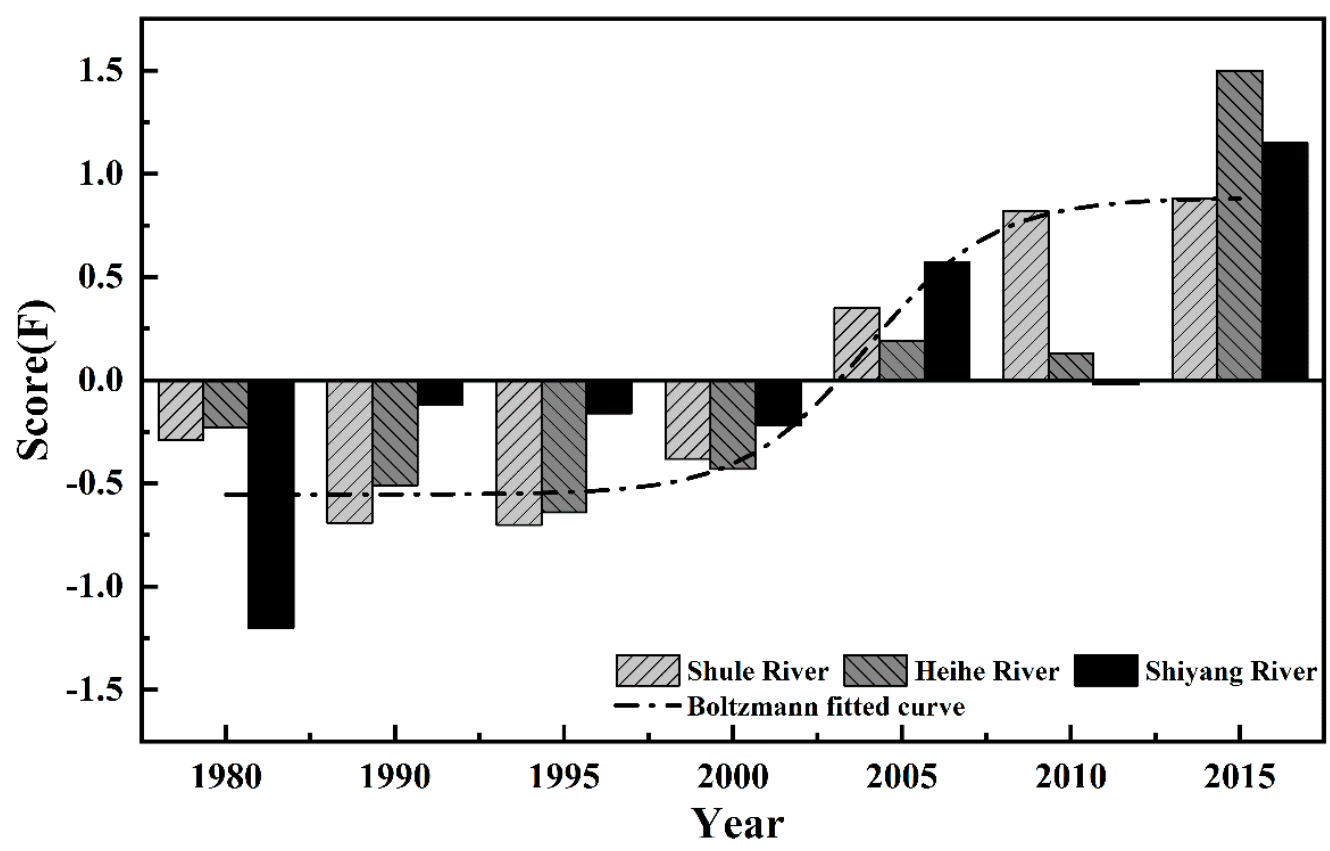

Figure 7. The trend of the driving forces score of the base flow change in Hexi inland rivers basin from 1980 to 2015.

As can be seen from the trend chart of the comprehensive driving force score $\mathrm{F}$ (Figure 7), the comprehensive driving force score F of the three basins in the Hexi inland river basin shows an upward trend, which indicates that the impact on the base flow is gradually enhanced by the climate factors and land-use changes. The negative driving force score before 2000 indicates that the driving force factor had little effect on the base flow, and the driving force has increased year by year since 2000 . The growth rate accelerated in about 2005. After 2010, except for the slowed rate in the Shule River basin, the growth rates of the Heihe River basin and Shiyang River basin increased rapidly. 
This is significantly related to the fluctuation in the second principal component in the Heihe River basin and Shiyang River basin, indicating that the influence of the climate factors on the base flow is gradually increasing. With the increase in temperature and precipitation, the effect of glacial melt water and precipitation recharge on the base flow is also gradually increasing. In addition, 2000 is a boundary point for the change trend in all the Hexi inland river basins, which is closely related to the change in the first principal component from negative to positive after 2000. Furthermore, the base flow trend of the Hexi inland river basin also initially decreased and then increased, which is consistent with the influence process of the comprehensive driving force factors on the base flow and the boundary point. This further shows that the change in the base flow of the Hexi inland river basin is controlled by the coupling of the climate factors and the land-use factor, both of which are indispensable.

\subsection{The Result of Double-Mass Curve}

It can be seen from the above results that the change of base flow in the Hexi inland river basin is mainly caused by the combined action of climate factors and land-use factors. These three climate factors contributed significantly to the principal components of different rivers (temperature to Shule River and Heihe River, PET to all three rivers, and precipitation to Heihe River and Shiyang River), and all land-use types for one or more rivers and components. However, it is necessary to further analyze which factors contribute more to the influence on the base flow. Therefore, based on the mutation characteristics and the analysis results of the factors influencing the base flow, the regression relationship between the accumulated base flow and the accumulated climate factors of the four rivers in the Hexi inland rivers basin in different periods was obtained using the double-mass curve method. However, there are two climate factors in each basin, and it is necessary to determine which climate factor has a high correlation with the base flow before calculating the double-mass curve. Therefore, based on the partial correlation analysis of the four rivers and the climate factors in the Hexi inland rivers basin, it was found that the correlation between the base flow and the temperature for the Shule River was the highest, with a partial correlation coefficient of 0.57 , and the partial correlation coefficient of the PET was 0.15 . The correlation between the base flow and precipitation was the highest for the Heihe River, with a correlation coefficient of 0.26 , followed by a partial correlation coefficient of 0.01 for temperature. For the Xiying River, the correlation between the PET and base flow was the highest, with a correlation coefficient of -0.34 , and the partial correlation coefficient for precipitation was -0.07 . The correlation between base flow and PET was the highest for the Zamu River, with a correlation coefficient of -0.24 , followed by a partial correlation coefficient of -0.07 for precipitation. In summary, the mutation point of the base flow was preliminarily taken as the boundary, and the annual climate factor and base flow series was divided into a reference period and change period for the comparative analysis. In order to further test the time periods, a nonparametric Mann-Whitney U test [66] was used to analyze the base flow at different time periods. The results showed that the significant values for the Shule River, Heihe River, Xiying River, and Zamu River were 0.000, 0.015, 0.022 , and 0.024 , respectively. These four values are all less than 0.05 , indicating that there is a statistical difference in the time periods of the base flow. The variation trend of the base flow is obviously changed among different periods, which indicates that the division of time periods is consistent with the variation characteristics of the base flow. Therefore, the reference period and change period are taken as the characteristic periods, and the corresponding double-mass curve is obtained. The regression relationship between the cumulative base flow and the accumulated temperature was established for the Shule River (Figure 8a), and the regression relationship between the cumulative base flow and the accumulated precipitation was established for the Heihe River (Figure 8b). Figure 8 c shows the regression relationship between the cumulative base flow and the cumulative PET for the Xiying River, and Figure 8d shows the regression relationship between the cumulative base flow and the cumulative PET for the Zamu River. 

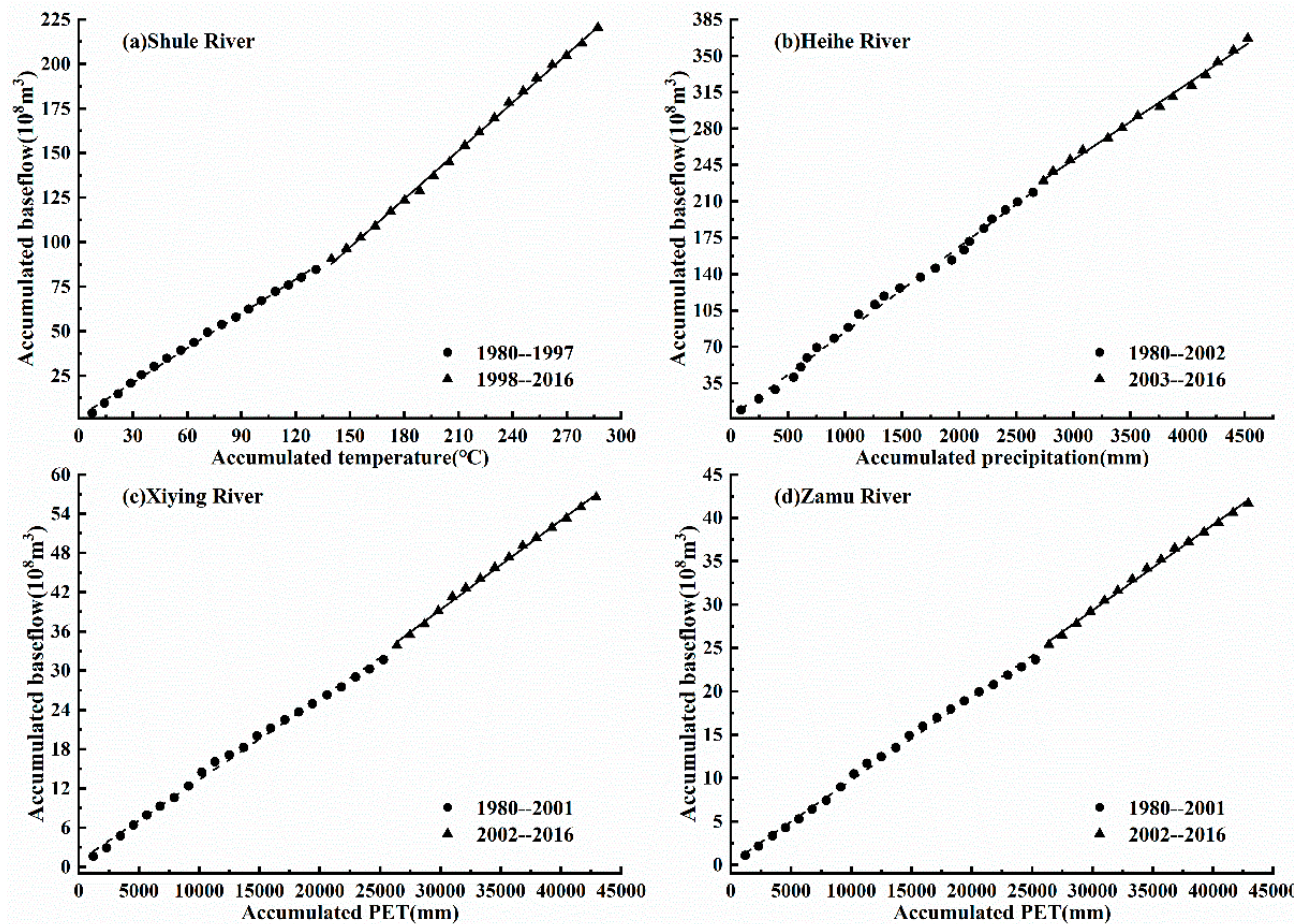

Figure 8. Double-mass curve of the climate-base flow of the Hexi inland rivers basin: (a) the Shule River; (b) the Heihe River; (c) the Xiying River; and (d) the Zamu River.

As can be seen from Figure 8 and Table 7, there is a significant correlation between the base flow and the climate factors in the reference period. Thus, it can be considered that the reference period is a period when the base flow change was less affected by the land-use change, and the climate factors were the main factors affecting the base flow change in this period. If the base flow in the change period was only affected by the climate factors, the trend in the hyperbolic curve should be consistent with the trend in the reference period. However, the slope of the fitting curve changed, which indicates that the land-use change led to a change in base flow to some extent.

Table 7. The variability of the double-mass curve in the different periods in the Hexi inland rivers basin.

\begin{tabular}{|c|c|c|c|c|}
\hline Basin & River & Period & Equation of Linear Regression & Coefficient of Correlation $\left(\mathbf{R}^{2}\right)$ \\
\hline \multirow{2}{*}{ Shule River basin } & \multirow{2}{*}{ Shule River } & 1980-1997 & $y=0.64 x+1.95$ & 0.9975 \\
\hline & & 1998-2016 & $y=0.90 x-38.47$ & 0.9986 \\
\hline \multirow{2}{*}{ Heihe River basin } & \multirow{2}{*}{ Heihe River } & 1980-2002 & $y=0.08 x+2.17$ & 0.9956 \\
\hline & & 2003-2016 & $y=0.07 x+30.37$ & 0.9949 \\
\hline \multirow{4}{*}{ Shiyang River basin } & \multirow{2}{*}{ Xiying River } & 1980-2001 & $y=1.24 \times 10^{-3} x+0.91$ & 0.9962 \\
\hline & & 2002-2016 & $y=1.37 \times 10^{-3} x-1.72$ & 0.9972 \\
\hline & \multirow{2}{*}{ Zamu River } & 1980-2001 & $y=9.56 \times 10^{-4} x+0.20$ & 0.9968 \\
\hline & & 2002-2016 & $y=9.88 \times 10^{-4} x-0.31$ & 0.9966 \\
\hline
\end{tabular}

\subsection{Analysis of Climatic Factors}

Climatic condition is an important factor that affects the change of base flow. Therefore, before calculating the contribution rate of climate factors and human activities to the change of baseflow, it is very important to understand the climate change trend in Hexi inland river basin. The trends of precipitation and temperature in the three basins during 1980-2016 are shown in Figure 9. 

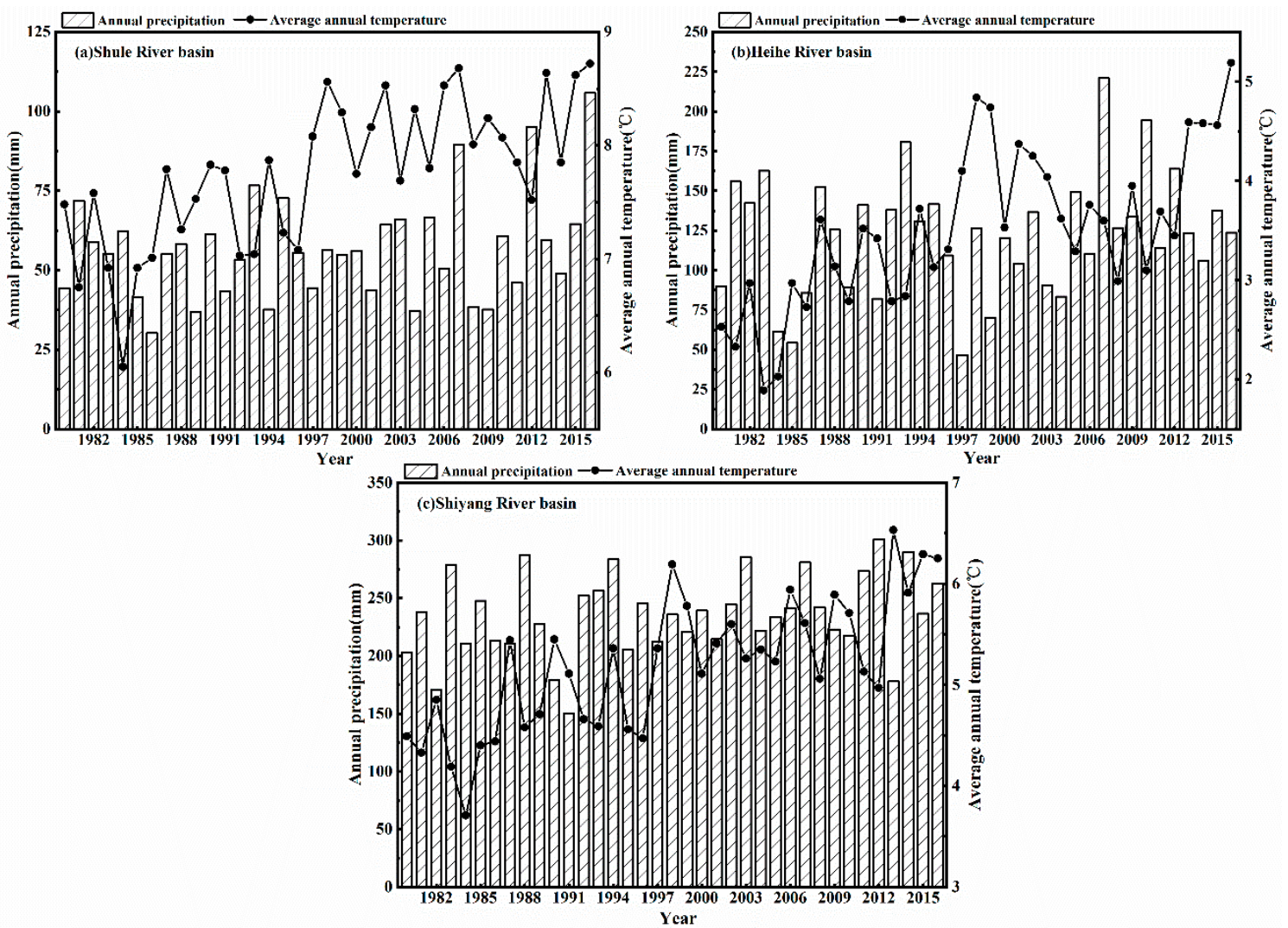

Figure 9. Diagram of annual precipitation and average annual temperature of the Hexi inland river basin during 1980-2016: (a) the Shule River basin; (b) the Heihe River basin; and (c) the Shiyang River basin.

As can be seen from Figure 9, on the whole, precipitation in the three basins of the Hexi inland river basin gradually decreased from east to west. In the past 40 years, the maximum annual precipitation in the Shiyang River basin was $235.50 \mathrm{~mm}$, which was followed by the Heihe River basin and Shule River basin. However, the climatic tendency rate of annual precipitation showed an increasing trend from east to west. The climatic trend rate of annual precipitation in the Shulehe River basin was the highest at $9.92 \mathrm{~mm} / 10 \mathrm{yrs}$, followed by the Heihe River basin $(7.20 \mathrm{~mm} / 10 \mathrm{yrs})$ and Shiyang River basin $(4.29 \mathrm{~mm} / 10 \mathrm{yrs})$. This is consistent with Lan Yongchao's research on the precipitation trend of the Hexi inland rivers basin [6]. This may be due to the continuous strengthening of circulation activities in the westerly zone and the increase of water vapor carried in the passage, which resulted in the significant increase of precipitation in the mountainous areas of the upper reaches of the Shule River and Heihe River located in the westerly climate zone. In addition, it can be seen that the precipitation values in the Hexi inland river basin after 2000 are all higher than those in 1980-2000.

Different from precipitation, the annual average temperature in the Hexi inland river basin does not decrease gradually from east to west, but the Shule River basin is the largest, followed by the Shiyang River basin and the Heihe River basin. At the same time, the order of the climate trend rate of annual average temperature is opposite to the order of annual average temperature. The Heihe River basin has the highest climate trend rate of $0.51{ }^{\circ} \mathrm{C} / 10$ yrs, followed by the Shiyang River basin $\left(0.46{ }^{\circ} \mathrm{C} / 10 \mathrm{yrs}\right)$ and Shulehe River basin $\left(0.42{ }^{\circ} \mathrm{C} / 10 \mathrm{yrs}\right)$. However, in general, the average annual temperature in the Hexi inland river basin shows an obvious increasing trend. In addition, the mutations of temperature in the Hexi inland river basin are all around 1997, which is consistent with Lan Yongchao's analysis of the abrupt change of temperature in the Hexi inland river basin [67]. The average temperature after 1997 was about $1^{\circ} \mathrm{C}$ higher than the average temperature before 1997. 


\section{Discussion}

\subsection{Non-Uniform Distribution of the Intra-Annual Base Flow}

It can be seen from Section 4.1 that the intra-annual base flow of the Hexi inland river presents a non-uniform distribution. This is due to the fact that the Hexi inland rivers originate from the Qilian Mountains, and the river recharge is dominated by the precipitation and glacial melt water in the mountainous areas. Both of these sources have seasonal characteristics, so the rivers have different recharge modes in each season. In winter, the temperature is low, and the amount of precipitation is relatively small. As the temperature increases, the glacial snow cover begins to melt in the spring and recharges the groundwater, which causes the base flow to gradually increase. However, at this time, the BFI value decreases. The reason for this is that the snowmelt channel alimentation as a quick flow component (surface flow, overland flow, direct flow) determines the decrease of $\mathrm{BFI}$ in springtime. What is more, the runoff is more sensitive to changes in precipitation and temperature, while the base flow is regulated by the aeration zone [68], so the change is relatively gentle. The river water supply mainly depends on the release of groundwater stored in the soil and near the surface during the summer [69]. In the flood season, the base flow is mainly supplied by precipitation infiltration. As the precipitation increased, the permafrost active layer, soil water, and groundwater were fully replenished, and the base flow also increased. Thus, the BFI value exhibited an obvious growth trend. At this point, the BFI values are all larger within one year, indicating that the base flow contributes more to the runoff. The proportion of ice and snow melt water recharge decreased rapidly after the precipitation infiltration decreased and the temperature decreased in autumn, which caused the base flow to begin to fall back. Therefore, the BFI value also began to decline slightly.

In addition, the intra-annual minimum BFI value of the Shule River occurred in July, which was different from that of the other three rivers. This is because the temperature and precipitation from May to August in the Shule River has replaced the base flow as the main factor affecting the change in runoff, and the degree of influence of the ice and snow melt water on runoff gradually increased or even exceeded that of precipitation [70].

\subsection{Contributions of the Influencing Factors to Base Flow}

In order to obtain the contribution rate of impact factors to the change of base flow, the reference period was used to restore the change period, i.e., the period that was less affected by land-use change, and the following conclusions can be drawn from Table 8 .

Table 8. Impacts of climate change and land-use change on the base flow in the Hexi inland rivers basin.

\begin{tabular}{|c|c|c|c|c|c|c|}
\hline Area & Period & $\begin{array}{l}\text { Segmented Base } \\
\text { Flow } / 10^{8} \mathrm{~m}^{3}\end{array}$ & $\begin{array}{l}\text { Calculated Base } \\
\text { Flow } / 10^{8} \mathrm{~m}^{3}\end{array}$ & $\begin{array}{c}\text { Total } \\
\text { Variation } / 10^{8} \mathrm{~m}^{3}\end{array}$ & $\begin{array}{l}\text { By Land-Use } \\
\text { Change/\% }\end{array}$ & $\begin{array}{l}\text { By Climate } \\
\text { Change } \% \%\end{array}$ \\
\hline \multirow{2}{*}{ Shule River } & 1980-1997 & 4.70 & - & - & - & - \\
\hline & 1998-2016 & 7.15 & 5.37 & 1.78 & 27 & 73 \\
\hline \multirow{2}{*}{ Heihe River } & 1980-2002 & 9.51 & - & - & - & - \\
\hline & $2003-2016$ & 10.59 & 11.08 & 0.49 & 55 & 45 \\
\hline \multirow{2}{*}{ Xiying River } & 1980-2001 & 1.44 & - & - & - & - \\
\hline & 2002-2016 & 1.66 & 1.50 & 0.16 & 27 & 73 \\
\hline \multirow{2}{*}{ Zamu River } & 1980-2001 & 1.08 & - & - & - & - \\
\hline & 2002-2016 & 1.20 & 1.17 & 0.03 & 75 & 25 \\
\hline
\end{tabular}

For the Hexi inland rivers, the base flow of the Shule River was most influenced by climate change, with a contribution rate of $73 \%$, and the maximum contribution rate of the land-use change to the change in base flow before and after the mutation point was $27 \%$. This is because climatic conditions such as precipitation and temperature affect the base flow by changing the amount of evaporation, infiltration, the recharge rates, and the time and the rate of snowmelt runoff $[71,72]$. The temperature changes in the western part of 
the Hexi inland rivers basin have maintained a good synchronization with the changes in the arid area of northwestern China and globally over the last 40 years. The heating rate is extremely fast, and the unique underlying surface conditions (e.g., low vegetation cover) cause the strong sensitivity of the surface temperature to global warming in this region [69]. At the same time, there are glaciers, snow cover, frozen soil, and other environmental factors that are closely related to temperature, and temperature becomes one of the main factors affecting the formation and change of runoff in mountainous areas. The spring temperature rises rapidly and generally reaches more than $0{ }^{\circ} \mathrm{C}$, and the snow accumulated in autumn and winter begins to melt, which replenishes the base flow.

The contribution rate of climate change to the base flow in the Heihe river basin was $45 \%$, and the contribution rate of land-use change was $55 \%$. This shows that the impacts of climate change and land use on the change in the base flow in the middle of the Hexi inland rivers basin were basically equal over the last 40 years. Unlike the Shule River, the average annual base flow of the Heihe river is not sensitive to temperature, but the degree of influence of precipitation on the base flow is relatively high. This may be related to the relatively low annual average temperature in the Heihe River basin. This indicates that compared with the western part of the Hexi inland rivers basin, the supply function of the ice snow melt water to the base flow is weaker in the central part. Therefore, the contribution rate of the climate factors to the change in the base flow in the middle reaches is lower than that in the western part.

The contribution rate of the land-use change to the base flow of the Zamu River is $75 \%$, followed by $27 \%$ for the Xiying River. This is due to the implementation of a number of major ecological projects in the Shiyang River basin, such as the land management policy, the fourth phase of the "three-north shelterbelt" project, the establishment of the Qilian Mountain Nature Reserve, and the comprehensive management of the Shiyang River basin [73], which was launched in 2006. With the increase in the planting of trees and grass, the area of grassland has increased, and the evaporation from vegetation and the infiltration rate of the soil have been reduced, which increased the yield of the base flow. This has improved the contribution rate of the land-use change to the change in the base flow, and it has increased the regional ecological carrying capacity, which has made the growth of the base flow better and more stable. As for the change in the base flow of the Xiying River in the western part of the Shiyang River basin, it is mainly controlled by the climate factors because compared with the eastern part, the western part is less ecologically fragile [74], and the influence of human activities is less severe. Thus, the base flow is mainly regulated by climatic factors.

Therefore, the contribution rate of the land-use change to the base flow of the Hexi inland rivers gradually weakens from east to west, except for the Xiying River, while the influence of climate change gradually increases, which is related to the gradual increase in the glacial frozen soil distribution from east to west and the progressive decline in human intervention. Under the influence of global warming and the circulation of the westerlies, the increase in ice and snow melt water as well as the degradation of the permafrost increase the recharge of the surface runoff to the base flow, and they slow down the water retreat in the basin. In addition, the decrease in human intervention also reduced the effect of the underlying surface changes on the base flow. All of these factors result in the base flow being more vulnerable to climate factors.

\section{Conclusions}

In order to obtain the base flow from the characteristics of each river basin in the Hexi inland rivers basin, through comparison of the various base flow segmentation methods, it was found that the most suitable base flow segmentation methods for each of the Hexi inland rivers are different. The methods of base flow segmentation for these three basins are the Lyne-Hollick filtering method (F1), the Boughton-Chapman filtering method (F3), and the Eckhardt filtering method (F4), respectively. 
In space, the amount of base flow in the various parts of the study area follows the order of Heihe, Shule, and Shiyang Rivers. The average annual base flow depth in the Heihe, Shule, Xiying, and Zamu Rivers were 95.38, 52.28, 105.52, and $171.21 \mathrm{~mm}$, respectively. Since the 1980s, the base flow of the Hexi inland rivers has all exhibited increasing trends, and the annual variations in their base flow have been relatively stable. The growth rate follows the order of western $>$ central $>$ eastern. The BFI values of the Hexi inland rivers are within the range of $0.45-0.65$. The annual average values of BFI in the Heihe, Shule, Xiying, and Zamu Rivers do not differ much, i.e., 0.569, 0.545, 0.486, and 0.487 , respectively. The mutation points of the base flow change in the Hexi inland rivers basin all occurred around 2000.

The change in the base flow in the Hexi inland rivers basin is the result of the coupling of climate factors and land-use change. As a result of the dissimilarity, the climates, and the underlying surfaces in each basin, the main factors affecting the base flow are also different. The main factor affecting the change in the base flow of the Shule River was temperature, while land-use change was the main factor for the Shiyang River. The Heihe River is controlled by precipitation and land-use change. Overall, the influence of land-use change on the base flow in the Hexi inland rivers basin gradually weakens from east to west, except for the Xiying River, while the influence of climate change gradually increases. The contribution rates of land-use change to the base flow in the eastern, central, and western regions were $75 \%, 55 \%$, and $27 \%$, respectively.

With continuous global warming, the glacier area will continue to decrease, and the active layer will continue to thicken. Thus, the supply of ice and glacier melt water and precipitation will continue to increase. Therefore, if the land-use type can be adjusted to change the underlying surface conditions, thereby increasing infiltration and reducing evapotranspiration, the healthy development of the base flow in the Hexi inland rivers basin can be effectively maintained, which is of great significance to solving the ecological water shortage problem and maintaining the local water security. However, due to the lack of actual observational data on glacial melt, frozen soil, and snow cover changes, it is difficult to further study the mechanism of the cryosphere's influence on the base flow under the background of global warming. The required data should be obtained through observation and simulation experiments. In addition, the impact of human activities is dominant and diverse. Determining a method to further quantitatively separate and evaluate the impact of different human activities on the hydrology of river basins is a problem that we intend to focus on in the future.

In addition, the time period used in this study is not long, which may make the demonstration of the results not strong enough. A longer data series would give a better picture of the impact of climate change on the base flow in the region. This point is also the direction that we should consider and improve in the future.

Author Contributions: Methodology, W.G., H.Z.; software, Y.L.; validation, Y.L.; formal analysis, Y.L.; investigation, J.Z., W.G., L.R.; writing—original draft preparation, Y.L.; writing—review and editing, Y.L.; supervision, X.J., L.R.; Funding acquisition, X.J.; project administration, X.J. All authors have read and agreed to the published version of the manuscript.

Funding: This research was supported by the National Natural Science Fund (51779209), and the National key research and development plan (2017YFC0404303).

Institutional Review Board Statement: Not applicable.

Informed Consent Statement: Not applicable.

Data Availability Statement: The data presented in this study are available on request from the corresponding author. The data are not publicly available due to privacy.

Conflicts of Interest: The authors declare no conflict of interest. 


\section{References}

1. Dai, M.Y. Base flow separation and characteristic analyses of tributaries in the middle reach of Yellow River. Yellow River 1996, 18, 40-43. (In Chinese)

2. Tallaksen, L.M. A review of baseflow recession analysis. J. Hydrol. 1995, 165, 349-370. [CrossRef]

3. Lan, Y.C.; Kang, E.S. Changing trend and features of the runoff from mountain areas of some main rivers in the Hexi inland region. J. Glaciol. Geocryol. 2000, 22, 147-152. (In Chinese)

4. Wang, Y.; Yang, H. Frozen ground degradation may reduce future runoff in the headwaters of an inland river on the northeastern Tibetan Plateau. J. Hydrol. 2018, 564, 1153-1164. [CrossRef]

5. Shi, Y.F.; Zhang, X. Influence and future trends of climate variation on water resources in the arid area in the northern China. Sci. China Ser. A Chem. 1995, 25, 968-977. [CrossRef]

6. Lan, Y.C.; Liu, J.P.; Ding, H.W.; Lu, C.Y.; Shen, Y.P.; Hu, X.L.; Gao, L.M. Changes of precipitation in mountainous areas of the three large inland river basins in the Hexi Corridor and their regional difference during 1960-2012. J. Glaciol. Geocryol. 2013, 35, 1474-1480. [CrossRef]

7. Zhang, Y.; Ma, J.; Chang, X.; Van Wonderen, J.; Yan, L.; Han, J. Water resources assessment in the Minqin Basin: An arid inland river basin under intensive irrigation in northwest China. Environment. Earth Sci. 2012, 65, 1831-1839. [CrossRef]

8. Zhang, T.; Zhou, Y.; Guo, D.; Qiu, G.; Cheng, G.; Li, S. Geocryology in China. Arct. Antarct. Alp. Res. 2001, 33, 245.

9. Wang, Q.F.; Zhang, T.; Wu, J.C.; Peng, X.; Zhong, X.; Mou, C.C.; Wang, K.; Wu, Q.; Cheng, G. Investigation of permafrost distribution over the upper reaches of the Heihe River in the Qilian Mountains. Glaciol. Geocryol. 2013, 35, 19-29. [CrossRef]

10. St Jacques, J.M.; Sauchyn, D.J. Increasing winter baseflow and mean annual streamflow from possible permafrost thawing in the Northwest Territories, Canada. Geophys. Res. Lett. 2009, 36, 329-342. [CrossRef]

11. Wang, Y.; Yang, D.; Lei, H.; Yang, H. Impact of cryosphere hydrological processes on the river runoff in the upper reaches of Heihe River. J. Hydraul. 2015, 46, 1064-1071. [CrossRef]

12. Connon, R.F.; Quinton, W.L.; Craig, J.R.; Hayashi, M. Changing hydrologic connectivity due to permafrost thaw in the lower Liard River valley, NWT, Canada. Hydrol. Process. 2014, 28, 4163-4178. [CrossRef]

13. Zhao, C.C.; Wang, Y.; Ding, Y.J.; Ye, B.S.; Yao, S.X. Spatial-Temporal Variations of temperature and precipitation in Northwest China in Recent 50 Years. Plateau Meteorol. 2011, 30, 385-390.

14. Shi, Y.F.; Shen, Y.P.; Hu, R.J. Preliminary study on signal, impact and foreground of climatic shift from warm-dry to warm-humid in Northwest China. J. Glaciol. Geocryol. 2002, 24, 219-226. [CrossRef]

15. Zhang, Y.; Fu, G.; Sun, B.; Zhang, S.; Men, B. Simulation and classification of the impacts of projected climate change on flow regimes in the arid Hexi Corridor of Northwest China. J. Geophys. Res. Atmos. 2015, 120, 7429-7453. [CrossRef]

16. Immerzeel, W.W.; Van Beek, L.P.H.; Konz, M.; Shrestha, A.B.; Bierkens, M.F.P. Hydrological response to climate change in a glacierized catchment in the Himalayas. Clim. Chang. 2012, 110, 721-736. [CrossRef] [PubMed]

17. Chen, Y.; Xu, C.; Chen, Y.; Li, W.; Liu, J. Response of glacial-lake outburst floods to climate change in the Yarkant River basin on northern slope of Karakoram Mountains, China. Quat. Int. 2010, 226, 75-81. [CrossRef]

18. Zhu, Y.H.; Wu, Y.Q.; Drake, S. A survey: Obstacles and strategies for the development of ground-water resources in arid inland river basins of Western China. J. Arid Environ. 2005, 59, 351-367. [CrossRef]

19. Mwakalila, S.; Feyen, J.; Wyseure, G. The influence of physical catchment properties on baseflow in semi- arid environments. J. Arid Environ. 2002, 52, 245-258. [CrossRef]

20. Zhang, H.; Zhang, B.; Zhao, C.Y. Annual base flow change and its causes in the upper reaches of Heihe River. Geogr. Res. 2011, 30, 1421-1430. [CrossRef]

21. Dong, W.W.; Ding, Y.J.; Wei, X. Variation of the base flow and its causes in the upper reaches of the Shule River in the Qilian Mountains. J. Glaciol. Geocryol. 2014, 36, 661-669. [CrossRef]

22. Zhang, J.; Song, J.; Cheng, L.; Zheng, H.; Wang, Y.; Huai, B.; Sun, W.; Qi, S.; Zhao, P.; Wang, Y.; et al. Baseflow estimation for catchments in the Loess Plateau, China. J. Environ. Manag. 2019, 233, 264-270. [CrossRef] [PubMed]

23. Quan, J.; Ma, J.L. Baseflow Separation and Its Characteristics Analysis in Shiyang River Basin. Water Resour. Power 2010, $28,15-17$.

24. Wei, H.D.; Li, Y.; Ding, F.; Chen, F.; Zhou, L.P.; Hu, X.K. Characteristics of climate change in Shiyang River Basin from 1951 to 2005. Pratacultural Sci. 2014, 4, 590-598. [CrossRef]

25. Meng, X.J.; Zhang, S.F.; Zhang, Y.Y. The Temporal and Spatial Change of Temperature and Precipitation in Hexi Corridor in Recent 57 Years. Acta Geogr. Sin. 2015, 67, 1482-1492.

26. Bai, M.; Niu, L.J.; Wei, R.N.; Zhen, X.J. Spatial and Temporal Distribution of Temperature in Hexi Corridor. J. Gansu Sci. 2019, 31, 46-48. [CrossRef]

27. Niu, Z.R.; Liu, J.Q.; Zhao, W.Z.; Ma, Z.Y. Study on the Impacts of Land Utilization on Surface Water Resources in Hexi inland rivers basin. J. China Hydrol. 2009, 29, 73-78. [CrossRef]

28. Yang, Z.N. Glacier Water Resources in China; Gansu Science and Technology Press: Lanzhou, China, 1991; pp. 1-158.

29. Wang, Y.; Li, Y.H.; Yao, Y.B.; Zhao, F.N. Spatial and Temporal Patterns in Surface Humidity Changes in the Shiyang River Basin. Resour. Sci. 2013, 35, 2112-2120.

30. Cheng, G.; Jin, H. Permafrost and groundwater on the Qinghai-Tibet Plateau and in northeast China. Hydrogeol. J. 2013, 21, 5-23. [CrossRef] 
31. Jiang, Y.W.; Zhang, X.F.; Yang, L.X.; He, C.S. Comparative Analysis of Temporal and Spatial Variations of Meteorological and Hydrological Drought Index in Upper Heihe River. Resour. Sci. 2014, 36, 1842-1851.

32. Sheng, Y.; Li, J.; Wu, J.C.; Ye, B.S.; Wang, J. Based on GIS characteristics of multi-year freeze-stop distribution in upper reaches of Shule River Basin. J. China Univ. Min. Technol. 2010, 39, 32-39.

33. Penman, H.L. Natural evaporation from open water, bare soil and grass. Proc. R. Soc. Lond. Ser. A Math. Phys. Sci. 1948, 193, 120-146. [CrossRef]

34. Allen, R.G.; Pereira, L.S.; Raes, D.; Smith, M. Crop PET-Guidelines for Computing Crop Water Requirements; United Nations Food and Agriculture Organization: Rome, Italy, 1998.

35. Posavec, K.; Bacani, A.; Nakic, Z. A visual basic spreadsheet macro for recession curve analysis. Groundwater 2006, 44, 764-767. [CrossRef]

36. Chen, L.Q.; Liu, C.M.; Li, F.D. Reviews on base flow researches. Prog. Geogr. 2006, 25, 1-15. [CrossRef]

37. Thomas, B.F.; Vogel, R.M.; Famiglietti, J.S. Objective hydrograph baseflow recession analysis. J. Hydrol. 2015, 525, 102-112. [CrossRef]

38. Jang, W.S.; Engel, B.; Ryu, J. Efficient flow calibration method for accurate estimation of baseflow using a watershed scale hydrological model (SWAT). Ecol. Eng. 2018, 125, 50-67. [CrossRef]

39. Bonneau, J.; Burns, M.J.; Fletcher, T.D.; Witt, R.; Drysdale, R.N.; Costelloe, J.F. The impact of urbanization on subsurface flow paths-A paired-catchment isotopic study. J. Hydrol. 2018, 561, 413-426. [CrossRef]

40. Blumstock, M.; Tetzlaff, D.; Malcolm, I.A.; Nuetzmann, G.; Soulsby, C. Baseflow dynamics: Multi-tracer surveys to assess variable groundwater contributions to montane streams under low flows. J. Hydrol. 2015, 527, 1021-1033. [CrossRef]

41. Furey, P.R.; Gupta, V.K. A physically based filter for separating base flow from streamflow time series. Water Resour. Res. 2001, 37, 2709-2722. [CrossRef]

42. Li, L.; Maier, H.R.; Partington, D.; Lambert, M.F.; Simmons, C.T. Performance assessment and improvement of recursive digital baseflow filters for catchments with different physical characteristics and hydrological inputs. Environ. Model. Softw. 2014, 54, 39-52. [CrossRef]

43. Nathan, R.J.; McMahon, T.A. Evaluation of automated techniques for baseflow and recession analyses. Water Resour. Res. 1990, 29, 1465-1473. [CrossRef]

44. Chapman, T.G.; Maxwell, A.I. Baseflow separation-comparison of numerical methods with tracer experiments. In Proceedings of the 23rd Hydrology and Water Resources Symposium, Hobart, Australia, 21-24 May 1996; Institution of Engineers: Camberra, Australia, 1996; Volume 5, pp. 539-545.

45. Boughton, W.C. A hydrograph-based model for estimating the water yield of ungauged catchments. In Proceedings of the Hydrology and Water Resources Symposium, Newcastle, Australia, 30 June-2 July 1993; Institution of Engineers: Camberra, Australia, 1993; Volume 14, pp. 317-324.

46. Dang, S.Z.; Wang, Z.G.; Liu, C.M. Baseflow separation and its characteristics in the upper reaches of the Heihe River basin. Resour Sci. 2011, 33, 2232-2237.

47. Arnold, J.G.; Allen, P.M.; Muttiah, R.; Bernhardt, G. Automated base flow separation and recession analysis techniques. Groundwater 1995, 33, 1010-1018. [CrossRef]

48. Eckhardt, K. A comparison of baseflow indices, which were calculated with seven different baseflow separation methods. J. Hydrol. 2008, 352, 168-173. [CrossRef]

49. Piggott, A.R.; Moin, S.; Southam, C. A revised approach to the UKIH method for the calculation of baseflow. Hydrol. Sci. J. 2005, 50, 911-920. [CrossRef]

50. Tang, Q.C.; Qu, Y.G.; Zhou, Y.C. Hydrology and Water Resources Utilization in Arid Areas of China; Science Press: Beijing, China, 1992; pp. $44-48$.

51. Lei, Y.N. Analysis on Trend and Driving Factors of Base Flow in Kuye Catchment; Research Center of Soil and Water Conservation and Ecological Environment, Chinese Academy of Sciences and Ministry of Education: Beijing, China, 2012.

52. Cheng, Q.-B.; Chen, X.; Xu, C.-Y.; Reinhardt-Imjela, C.; Schulte, A. Improvement and comparison of likelihood functions for model calibration and parameter uncertainty analysis within a Markov chain Monte Carlo scheme. J. Hydrol. 2014, 519, $2202-2214$. [CrossRef]

53. Burn, D.H.; Elnur, M.A.H. Detection of hydrological trend and variability. J. Hydrol. 2002, 255, 107-122. [CrossRef]

54. Zhang, X.P.; Zhang, L.; Wang, Y.; Mu, X. Tempo-spatially responses of the annual streamflow to LUCC in the middle reaches of Yellow River, China. Sci. Soil Water Conserv. 2009, 7, 19-26. [CrossRef]

55. Zhang, Y.-F.; Wang, X.-P.; Hu, R.; Pan, Y.-X. Meteorological influences on process-based spatial-temporal pattern of throughfall of a xerophytic shrub in arid lands of northern China. Sci. Total Environ. 2018, 619-620, 1003-1013. [CrossRef]

56. Wu, J.W.; Miao, C.Y.; Zhang, X.M. Detecting the quantitative hydrological response to changes in climate and human activities. Sci. Total Environ. 2017, 586, 328-337. [CrossRef] [PubMed]

57. Liu, E.J.; Zhang, X.P.; Xie, M.L.; Chen, N.; Zhang, T.T.; Guo, M.J.; Zhang, J.J. Hydrologic responses to vegetation restoration and their driving forces in a catchment in the Loess hilly-gully area: A case study in the upper Beiluo River. Acta Ecol. Sin. 2015, 35, 622-629.

58. Ryberg, K.R.; Hodgkins, G.A.; Dudley, R.W. Change points in annual peak streamflows: Method comparisons and historical change points in the United States. J. Hydrol. 2020, 583, 124307. [CrossRef] 
59. Wei, F.Y. Modern Statistical Climate Diagnosis and Prediction Techniques; China Meteorological Press: Beijing, China, 2007; pp. 57-60.

60. Van Engelenburg, J.; Hueting, R.; Rijpkema, S.; Teuling, A.J.; Uijlenhoet, R.; Ludwig, F. Impact of changes in groundwater extractions and climate change on groundwater-dependent ecosystems in a complex hydrogeological setting. Water Resour. Manag. 2018, 32, 259-272. [CrossRef]

61. Koskelo, A.I.; Fisher, T.R.; Utz, R.M.; Jordan, T.E. A new precipitation-based method of baseflow separation and event identification for small watersheds $\left(<50 \mathrm{~km}^{2}\right)$. J. Hydrol. 2012, 450-451, 267-278. [CrossRef]

62. Li, X.; Wang, G.; Xu, T.; Huang, W. Varimax-Based Rotation Algorithm for Factor Analysis. Nanotechnol. Precston Eng. 2013, 11, 557-561. [CrossRef]

63. Jiao, J.Z. The Study of Temporal-Spatial Changing and Simulation of Land-Use/Cover in Minqin Oasis. Ph.D. Thesis, Lanzhou University, Lanzhou, China, 2012; pp. 77-87.

64. Zhou, G.L.; Liang, H. Factor score, principal component score coefficient calculation are referred to some papers. J. Nat. Resour. 2006, 21, 827-833.

65. Fu, X.; Ji, C.M. A comprehensive evaluation of the regional water resource carrying capacity-Application of main component analysis method. Resour. Environ. Yangtze Basin 1999, 8, 168-173.

66. Cagdas, C.; Sait, B. Relationship between Academicians' Organizational Identification Levels and Cynicism Attitudes in Sports Sciences. Eur. J. Educ. Res. 2019, 8, 349-360. [CrossRef]

67. Lan, Y.; Hu, X.; Ding, H. Multiple Time Scales Analysis of Jump and Variation of Air Temperature in Mountain Area of Hexi Inland River Basin in the Past More than 50 Years. Mt. Res. 2014, 32, 163-170.

68. Zu, M.J.; Guan, Y.Q.; Zhang, D.R.; Shen, X.J.; Li, X.H.; Shao, G.W. Analysis of base flow variation characteristic in Hailiutu river in past 50 years. J. Water Resour. Water Eng. 2013, 24, 38-42.

69. Ding, Y.J.; Ye, B.S.; Liu, S.Y. Effect of climatic factors on streamflow in the Alpine catchment of the Qilian Mountain. J. Geogr. 1999, 54, 431-437.

70. Xu, H.J.; Yang, T.B.; Zhang, X.X. Climate change in upstream area of Shule River and its effects on runoff yield in last 50 years. Bull. Soil Water Conserv. 2014, 34, 39-45.

71. Tague, C.; Grant, G.E. Groundwater dynamics mediate low-flow response to global warming in snow-dominated alpine regions. Water Resour. Res. 2009, 45, W07421. [CrossRef]

72. Barnhart, T.B.; Molotch, N.P.; Livneh, B.; Harpold, A.A.; Knowles, J.F.; Schneider, D. Snowmelt rate dictates streamflow. Geophys. Res. Lett. 2016, 43, 8006-8016. [CrossRef]

73. Jiang, X.R.; Li, D.; Pang, G.J. Analysis of land use/cover change and its driving factors in Shiyang River basin in the early 21 century. J. Arid Land Resour. Environ. 2010, 24, 61-66. [CrossRef]

74. Jia, J.J.; Zhao, J.; Wang, J.B.; Gao, C.; Chang, R.Y. Ecological vulnerability assessment of Shiyang River basin based on SRP model. J. Arid Land Resour. Environ. 2020, 34, 34-41. (In Chinese) 